\title{
Türkiye Havayolu İç Hat Şehir Çiftlerindeki Pazar Yapılarının Piyasa Yoğunlaşması Ölçütleri ile Belirlenmesi
}

\author{
Mehmet YAŞAR* $\quad$ Ender GEREDE **
}

\begin{abstract}
$\ddot{O} Z$
Türkiye'de 1983 ve 2003 yıllarında havayolu taşımacıllı̆ı pazarındaki ekonomik düzenlemelerin serbestleştirilmesinin temel amacı rekabeti artırarak pazarın büyütülmesidir. 1983 yllındaki serbestleşme iç hatlar pazarında kayda değer olumlu bir sonuç yaratmazken 2003 yılındaki serbestleşmeden sonra iç hatlar pazarının önemli ölçüde büyüdüğ̈̈ bilinmektedir. Bununla birlikte büyümenin iç hatlarda yeni şehir çiftlerinin devreye girmesiyle mi yoksa daha önceden hizmet götürülen şehir çifti pazarlarındaki rekabetin artmastyla mı oluştuğu araştırmaya değer bir konudur. Herhangi bir pazarda gerçekleştirilen ekonomik faaliyetlerin az sayıda işletme tarafindan yürütülmesi anlamına gelen piyasa yoğunlaşmasının artması rekabeti olumsuz yönde etkilemektedir. Yoğunlaşmanin yüksek olduğu piyasalar monopol ve düopol pazarlara işaret etmektedir. Bu çalışmada Türkiye iç hatlarında şehir çifti pazarlarındaki yoğunlaşma derecesi ölçülerek pazara girişin serbestleştirilmesinin temel amacı olan rekabet artışının durumu ortaya konmuştur. Yolcu sayıları üzerinden her bir şehir çifti için havayolu işletmelerinin pazar payları belirlenmiş ve 2012 ve 2014 yılları arası temel alınarak toplam 1447 şehir çifti için yoğunlaşma değerleri hesaplanmıştır. Hesaplamalar yapılırken piyasa yoğunlaşması ile ilgili ölçüm araçları olan N firma yoğunlaşma oranı, Herfindahl-Hirschmann Endeksi ve Entropi Endeksi kullanılmıştır. Sonuç olarak pazarların çok büyük bir bölümünün monopol, önemli bir bölümünün düopol olduğu ve çok az sayıda şehir çiftinin oligopol ve oligopole yakın özellikler taşıldı̆̆ anlaşılmıştır. Şehir çifti pazarları yolcu sayıları üzerinden değerlendirildiğinde yoğunlaşmanın rekabeti olumsuz yönde etkileyecek kadar yüksek olduğu sonucuna varllmıştır.
\end{abstract}

Anahtar Kelimeler: Pazar yoğunlaşmasl, Türkiye iç hatlar yolcu pazarl, HerfindahlHirschmann Endeksi, N firma yoğunlaşma oranı, Entropi Endeksi.

JEL Sinıflandırmast: A12, D40, L93

\section{Identifying the market structure by market concentration measures in Turkish domestic airline city pair markets}

\begin{abstract}
The main motivation behind the airline market deregulation in Turkey in 1983 and 2003 is to enlarge the airline market by increasing the competition. The deregulation in 1983 did not produce a significant and constructive result in the domestic routes. On the other hand the domestic market have been significantly grown due to deregulation in 2003. However it is worth investigating whether the market has grown due to the fact that new city pair markets have become part of the domestic routes or that there have been an increase in competition in previously served city pair markets. Increasing market concentration, which means that a small number of companies conduct economic activity in any market, affects competition negatively. Therefore, there is an inverse
\end{abstract}

\footnotetext{
* Araş. Gör. Anadolu Üniversitesi, Havacılık ve Uzay Bilimleri Fakültesi, Havacılık Yönetimi Bölümü. email: mehmet_yasar@anadolu.edu.tr

** Doç. Dr. Anadolu Üniversitesi Havacılık ve Uzay Bilimleri Fakültesi, Havacılık Yönetimi Bölümü email: egerede@anadolu.edu.tr
} 
correlation between competition and market concentration which means that economic resources and activities are controlled by a few companies. High concentrated markets indicate monopoly and duopoly markets. In this study, the degree of concentration in the domestic city pair markets was measured and the situation of the increase of competition which is the main aim of the liberalization of the market entry was revealed. In this study, domestic airlines' origin-destination passenger numbers were analyzed. The market shares of airlines for each city pair have been determined on the said numbers and based on the years 2012 and 2014 concentration values for the total 1447 city pairs have been calculated. $N$ concentration ratio, the Herfindahl-Hirschmann Index and the Entropy Index were used to measure the market concentration rate. As a result, it has been understood that a large part of the city pair markets is monopoly, a significant part is the duopoly and very few city pair markets show oligopoly and near oligopoly characteristics. When the city pairs markets are evaluated on the number of origin destination passengers, it is concluded that the market concentration rate is high enough to affect the competition negatively.

Key Words: Market concentration; Turkish domestic airline passenger market, Herfindahl-Hirschmann Index, $N$ concentration ratio, Entropy Index

JEL Classification: A12, D40, L93

\section{GíRiş}

Türk havayolu taşımacılığı tarihindeki en önemli iki kırılım noktası 1983 ve 2003 yıllarındaki havayolu pazarını serbestleştirmeye yönelik politika değişimleridir (Gerede, 2010; Gerede ve Orhan, 2015, s. 167). Bu politika değişimlerinin temel amacı ise havayolu taşımacılığındaki ekonomik düzenlemeleri serbestleștirerek rekabeti $\operatorname{artırmak}^{1}$ ve bu sayede pazarın büyütülmesini ve Türk Havayolu Taşımacıllğı Sektörünün geliştirilmesini sağlamaktır. Nitekim pek çok akademik araştırma havayolu pazarına ilişkin ekonomik düzenlemelerin serbestleştirilmesinin havayolu işletmeleri arasındaki rekabeti artırdığı için tarife ve konfor temelli havayolu ürünü bileşenlerindeki hizmet kalitesinin arttığını, buna karşın bilet fiyatlarının düştügünü göstermektedir (Wensveen, 2007, s.177; Dresner ve Tretheway, 1992; Maillebiau ve Hansen, 1995). Kuşkusuz bu sonuçlar havayolu taşımacılığına olan talebi artırmakta (Fu vd., 2010; Dresner ve Windle, 1992) ve bunun sonucunda sektör de büyümektedir.

Buna karşın, Türkiye havayolu taşımacılığı pazarındaki ekonomik düzenlemeleri konu alan sınırlı sayıda çalışma dikkate alındığında 1983 yılındaki serbestleşmenin iç hatlar pazarını yeterince büyütemediği görülmektedir. Bunun sebebini açıklayan en geçerli varsayım seçeneği serbestleşmeye rağmen iç hat pazarındaki rekabetin artmamış olmasıdır. Diğer yandan 2003 yılındaki iç hat serbestleşmesi sonrasında iç hatlarda taşınan yolcu sayısında tarihin en önemli artışları gözlenmiştir. Sonuç olarak 2003 yılındaki iç hatlar serbestleşmesinin yolcu trafiği artışı açısından istenilen sonuçları yarattı̆̆ söylenebilir. Nitekim

\footnotetext{
${ }^{1}$ 11.4.2001 tarihinde Türk Sivil Havacılık Kanununda Değişiklik Yapılması Hakkında Kanun Tasarısının Genel Gerekçesinde '2.4.2001 tarihli ve 24362 sayılı Resmi Gazete 'de yayımlanan SHY6A yönetmeliğindeki değişiklikle birlikte sektöre yeni işletmelerin girmesinin kolaylaşması ve işletmeci sayısının artması' ibareleri yer almaktadır. Ayrıca 1983 tarihli 2920 sayılı Türk Sivil Havacılık Kanununun 25. Maddesinin iç hat hava taşımacılığında özel havayolu işletmeleri için rekabetin önünde engel olduğu ve 25 maddede rekabeti artırmak gerekçesiyle değişiklik yapılacağı belirtilmiştir.
} 
konuya ilişkin araştırmalar, küresel ölçekte iç ve dış hatlardaki ekonomik düzenlemelerin giderek serbestleştirildiği ve rekabetin arttığını göstermekteyken, bu alandaki ders kitapları havayolu taşımacılığı pazarının oligopol bir yapıda olduğunu vurgulamaktadır. Diğer yandan serbestleşmenin, dünya örneklerine bakıldığında, ilk aşamada pazara giren havayolu işletmesi sayısını artırdığı fakat sonrasında pazarın serbestleşme öncesine göre daha fazla oligopol bir yapıya büründüğü ve havayolu işletmeleri arasında fiyat rekabeti olmadığı ileri sürülmektedir (Hanlon, 2007:113; Holloway, 2008, s.131). Bu noktada trafik artışında rekabetin rolünün belirlenmesi önemli bir araştırma problemi olarak karşımıza çıkmaktadır. İç hatlar pazarında rekabetin gerçekten artıp artmadığı ve büyümenin iç hatlarda yeni şehir çiftlerinin devreye girmesiyle mi yoksa daha önceden hizmet götürülen şehir çifti pazarlarındaki rekabetin artmasıyla mı oluştuğu araştırmaya değer bir konudur. Fakat 2012 yılından önce iç hatlar pazarında Başlangıç Noktası - Varış Noktası (BN-VN) pazarlarındaki trafik miktarı bilinemediği için şehir çifti pazarlarındaki rekabet açısından piyasa yapısını tespit etmek mümkün olamamıştır. Bu da trafik artışına yeni hatların eklenmesinin mi, mevcut hatlardaki rekabet artışının mı yoksa her ikisinin de mi sebep olduğunun öğrenilmesini engellemektedir. Devlet Hava Meydanları İşletmesi Genel Müdürlüğü (DHMI), 2012 yılından itibaren BN-VN trafik verilerini belirleyip yayınlamaya başlamış, şehir çifti bazındaki pazar yapısı araştırmaları mümkün hale gelmiştir.

Bu çalışmanın amacı, Türkiye iç hatlarındaki ekonomik düzenlemelerden, pazara giriş bileşeninin serbestleştirilmesinin temel amacı olan rekabet artışının durumunu ortaya koymak ve değerlendirmektir. Bunun için piyasa yapısı ve rekabet hakkında bilgiler veren yoğunlaşma derecesinin şehir çifti pazarlarındaki durumunun ölçülmesi ve durumun değerlendirilmesi hedeflenmiştir.

\section{KAVRAMSAL ÇERÇEVE VE YAZIN İNCELEMESI}

\section{A. Havayolu Taşımacılığı Pazarı}

Havayolu ürünü yolcunun, yükün ya da postanın iki nokta arasında havayolu taşımacılı̆̆ Fakat tanımda sözü edilen iki nokta üzerindeki havaalanları yolcunun ulaşım ihtiyacını karşılayacak asıl başlangıç ve varış noktaları üzerinde olmayabilir. Asıll Seyahat Başlangıç Noktası (ASBN) - Asıl Seyahat Varış Noktaları (ASVN) ile havayolu taşımacılığı hizmetinin başlangıç ve bitiş noktaları aynı ya da farklı olabilir. ASBN-ASVN, kullanılan ulaşım seçeneği türüne bakılmaksızın, kapıdan - kapıya taşımacılığın yapılacağı noktaları temsil etmektedir (Gerede, 2015:6). Bu nedenle her havaalanı çifti arasındaki seyahat yolcunun yer değiştirme ihtiyacı duyduğu asıl iki noktaya karş1lı gelmez (Belobaba, 2009: 52). Örneğin yolcu Ankara'dan İstanbul aktarmalı olarak Dalaman'a gidiyorsa asıl havayolu ürünü ne Ankara - İstanbul ne de İstanbul - Dalaman uçuşudur. Asıl havayolu ürünü Ankara-Dalaman uçuşudur. Çünkü yer değiştirme ihtiyacı Ankara-Dalaman arasında ortaya çıkmıştır. Dolayısıyla asıl havayolu talebi Ankara-Dalaman arasındaki uçuş ürünü içindir. Çok bacaklı uçuşlarda seyahatin asıl başladığı 
nokta ile asıl varış yeri dikkate alınmadığında konuya ilişkin pazar, talep ve rekabet gibi alanlarda yapılan araştırmalar yanlış sonuçlar verecektir. İngilizce yazında asıl havayolu ürününe karşılık olarak "Origin-Destination" (O-D ya da O\&D) terimi kullanılmaktadır. Gerede (2015) çalışmasında çok bacaklı uçuşlarda asıl havayolu ürününe karşılık gelecek terim olarak "Asıl Başlangıç ve Asıl Varış" (AB-AV) noktası isimlendirmesini önermektedir.

Türkiye iç hatlar pazarında havaalanları arasındaki yolcu trafiğine ilişkin istatistikleri DHMİ tutmakta ve yayınlamaktadır. Fakat 2012 yılına kadar yayınlanan istatistikler her bir havaalanına geliş ve gidiş trafiklerini içermektedir. Gelen yolcuların ASBN'si, giden yolcuların ise ASVN'si bilinmemektedir. Bu durum şehir çifti pazarlarına özgü analizlerin yapılmasını engellemiştir. DHMİ'nin 2012 yılından itibaren AB-AV trafik miktarı değerlerini de tutup yayınlamaya başlaması bu tür analizlerin yapılabilmesinin önünü açmıştır.

Havayolu pazarı belirli iki nokta arasında havayolu ürününü sunanlar ile bu ürünü talep edenlerin karşı karşıya geldiği ve fiyatın belirlendiği yer olarak tanımlanmaktadır. Havayolu pazarlarına verilebilecek en yaygın örnek, İstanbulParis örneğinde olduğu gibi, şehir-çifti pazarlarıdır. Ancak bazı şehirlerde birden fazla havaalanı olduğundan havaalanı-çifti pazarları ortaya çıkar. Havaalanı çiftleri aynı iki bölge ve şehri birleştirse de, AB ve AV noktaları farklı olduğundan, iki ayrı havayolu ürünü söz konusudur (ICAO, 2004:4.1.1). Sözü edilen iki farklı ürün coğrafi açıdan ASBN-ASVN arasındaki toplam seyahat süresine ilişkin yolculara farklı avantaj ve dezavantajlar sunabilir. Buna karşın aralarındaki mesafe kısa olduğu için bu iki havayolu ürünü kolayca birbirini ikame edebilirler ve sözü edilen havaalanı çiftleri paralel hat olarak adlandırılırlar. İstanbul'daki Atatürk ve Sabiha Gökçen Havaalanları ile Paris'te bulunan Orly ve Charle De Gaulle Havaalanları benzer pazarları oluşturur (Gerede, 2015: 15). Çok sayıda şehir ya da havaalanı çiftlerini kapsayan bölgeler de tek bir pazar ya da pazar bileşeni olarak görülebilir. İç hat ya da dış hat pazarları, ülke çifti pazarları ya da kitalar arası pazarlar gibi.

Rekabet konusundaki çalışmalar açısından bakıldığında pazar tanımlarının hem ürünün kendisini (ilgili ürün pazarı) hem de ürünün pazarlandığı coğrafi bölgeyi (coğrafi pazar) kapsadığı görülmektedir. Fakat havayolu ürününün özünde coğrafi olarak yer değiştirme hizmeti olduğu için ürünün kendisi ve sunulduğu coğrafi bölge iç içe geçmiş durumdadır (Gerede, 2015: 15).

Gerede (2015) çalışmasında, 1997/1 sayılı Rekabet Kurulu'ndan İzin Alınması Gereken Birleşme ve Devralmalar Hakkında Tebliğ'in 4 üncü maddesindeki ${ }^{2}$ tanımı değerlendirmekte ve ürüne ilişkin 3 özelliğe vurgu yapıldığını belirtmektedir. Bunlar; (1) ürünün fiyatı, (2) ürünü niteleyen özellikler, (3) ürünün kullanım amacı. Ürünün fiyatı ve ürünü niteleyen özellikler havayolu ürününün bileşenlerindendir. Bunlara ek olarak "İlgili Pazar" tanımı yapılırken ürünün kullanım amacının da dikkate alındığı anlaşılmaktadır.

${ }^{2}$ 12.08.1997 tarih ve 23078 sayılı Resmi Gazete'de yayımlanmıs olan. 
Havayolu ürünün temel kullanım amacı hızlı yer değiştirmektir. Hızlı yer değiştirme ihtiyacının çoğunlukla iki şekilde ortaya çıktığ 1 bilinmektedir: "IŞş amaçll" ve "eğlence amaçlı"(O'Connor, 2001, s.103).

İş amaçlı yolcular zamana duyarlıdır ve istedikleri yerden istedikleri yere istedikleri zamanda, gecikmesiz ve en kısa sürede ulaşmak isterler (Shaw, 2007, s.34-40). İş amaçlı yolcuların bu ihtiyaçları karşılanmazsa başka bir havayolu işletmesine ya da alternatif ulaşım seçeneklerine (rakiplere ya da ikame ürünlere) kaymaları olasıdır. Eğlence amaçlı yolcular ise zamana değil daha çok fiyata duyarlıdır. Zamana duyarlı olan iş amaçlı yolcular, toplam seyahat sürelerini kısaltan doğrudan uçuşları tercih ederken eğlence amaçlı yolcular fiyat avantajı elde ettiklerinde, toplam seyahat süreleri uzasa bile, bağlantılı uçuşları tercih edebilirler. Bu nedenle eğlence amaçlı yolcuların önünde çok daha fazla ikame ürün seçeneği bulunmaktadır (Gerede, 2015: 19).

Rekabet Kurulu tarafindan 1997/1 sayılı Tebliğ'de yapılan coğrafi pazara ilişkin tanımda rekabet koşulları açısından birbirinden ayrılan bölgelere işaret edilmektedir. Tanım şu şekildedir: "Coğrafi pazar, teşebbüslerin mal ve hizmetlerinin arz ve talebi konusunda faaliyet gösterdikleri, rekabet koşullarının yeterli derecede homojen ve özellikle rekabet koşulları komşu bölgelerden hissedilir derecede farklı olduğu için bu bölgelerden kolayca ayrılabilen bölgelerdir" (Rekabet Kurumu, 2008:2-3). Tanıma göre rekabet koşulları coğrafi pazar olarak tanımlanacak bölge içinde yeterince homojenken diğer bölgelerden kolayca ayırt edilecek özelliklere sahip olmalıdır. Çok sayıda şehir ya da havaalanı çiftini barındıran bir bölgedeki rekabet koşulları kendi içinde benzerken diğer bölgelerden farklı özellikler taşıyorsa söz konusu bölgeler de topyekûn bir "coğrafi pazar" olarak görülebilir. Bu durumda Türkiye iç hatlar ve dış hatlar pazarlarındaki rekabet koşullarının birbirinden farklı özellikler taşıdığından, bu nedenle iki farklı coğrafi pazarın varlığından söz edilebilir (Gerede, 2015: 21).

\section{B. Serbestleşme Uygulamalarının Etkilerinin İncelenmesi}

1983 yılında yürürlüğe giren 2920 Sayılı Sivil Havacılık Kanunu ile özel havayolu işletmelerinin kurulması ve taşımacılık faaliyetlerinde yer almasının önündeki engeller, başka bir deyişle pazara girişin önündeki en büyük engel kaldırılmıştır. Bunun bir sonucu olarak birçok havayolu işletmesi kurulmuştur (Gerede ve Orhan, 2015, s. 172). Fakat Gerede'nin (2010) çalışması 1983 yılındaki serbestleşmenin iç hatları değil daha çok dış hat havayolu taşımacılığ 1 pazarını büyüttüğünü, buna karşın Avrupa'da özellikle etnik nüfusun yaşadığı ülke ve şehir çifti pazarlarında faaliyet gösteren havayolu işletmelerinin sayısının ve buna bağlı olarak tarifesiz havayolu pazarındaki rekabetin artmış olduğunu göstermektedir. Tablo 1'de de görüldüğü gibi özel Türk havayolu işletmelerinin iç hatlarda taşıdıkları yolcu sayısı oranları dış hatlara göre oldukça sınırlı kalmıştır. 
Tablo 1. Özel Türk Havayolu İşletmelerinin İç-Dış Hatlarda Yolcu Sayısı Oranları

\begin{tabular}{ccc}
\hline Yıllar & $\begin{array}{c}\text { Dış Hat } \\
\text { \% }\end{array}$ & $\begin{array}{c}\text { İç Hat } \\
\text { \% }\end{array}$ \\
\hline 1988 & 23,3 & 6,6 \\
1989 & 29,6 & 4,1 \\
1990 & 34,9 & 6,8 \\
1991 & 52,6 & 13,4 \\
1992 & 55,9 & 17,1 \\
1993 & 57,4 & 11,7 \\
1994 & 55,7 & 6,7 \\
\hline
\end{tabular}

Kaynak: Gerede, 2010, s.84

Gerede (2010) çalışmasında, iç hatlarda Bursa Havayolları ve Sönmez Havayolları gibi Bursa-İstanbul pazarında tarifeli seferler düzenleyen niş havayolu işletmeleri olduğunu fakat bunların faaliyet ölçeği ve kapsamının çok sınırlı kaldığını belirtmektedir. Ayrıca Türkiye'nin daha önemli iç hat pazarlarında İstanbul Havayolları'nın tarifeli seferler düzenlemek istediğini fakat her seferinde pazara girmekte büyük güçlüklerle karşılaştığını vurgulamaktadır. Gerede'ye (2010, s. 88) göre 1983 y1lındaki serbestleşmeden sonra iç hatların gelişmemesinde rol oynayan faktörler şunlardır:

- Pazara giriş serbest olmasına rağmen, özellikle THY'nin özelleştirme kapsamına alınmasına bağlı olarak, uygulamada sıkı düzenlemelerin olmas1,

- Özel sektör havayolu işletmelerinin karlı şehir çifti pazarlarına girmelerine engel olunmas1,

- Buna bağlı olarak rekabet ortamının sağlanamaması,

- Bilet fiyatlarının yüksek olması,

- Türkiye'de gelir seviyesinin düşük olması,

- Devletin havayolu taşımacılığını lüks bir ulaşım modu olarak görmesi nedeniyle ek vergiler koymas1,

- Kısa mesafeli hatlara uygun filo planlamasının yapılamamış olması.

Gerede'nin (2010) çalışması incelendiğinde 1983 yılındaki serbestleşmenin Türkiye'deki iç hatlar pazarının gelişmesini sağlayamadığı görülmektedir. $\mathrm{Bu}$ olumsuz sonuçta iç hatlarda tekrar uygulamaya konan sık1 pazara giriş düzenlemelerinin önemli rol oynadığı ileri sürülmektedir. 1983 yılındaki serbestleşme özel havayolu işletmelerinin pazarda havayolu taşımacılığ 1 faaliyetlerinde bulunmasının önünü açmış olsa da sonrasında getirilen yeni sıkı düzenlemelerle birlikte istenilen serbest pazar ortamı oluşmamıştır. Sonuç olarak iç hatlar pazarı 2003 yılındaki serbestleşme uygulamasına kadar THY'nin tekelinde kalmıştır (Dursun vd., 2014, s. 108). 2003 yılının Ekim ayında özel havayolu işletmelerinin iç hat pazarına girmesinin önündeki engel olan 1996 yılında alınan SHGM kararları (Gerede, 2011, s. 511) kaldırılmış ve özel 
havayolu işletmelerinin pazara girişi tekrar serbest hale getirilmiştir (Gerede ve Orhan, 2015, s. 187). Pazara giriş serbestleştirildikten sonra ise yeni havayolu işletmeleri pazarda hizmet vermeye başlamış ve THY'nin domine ettiği monopol pazar günümüzdeki haline evrilmiştir.

1984-2003 yılları arasında dış hatlardaki yolcu sayısı artışı \%1689 iken, iç hatlardaki yolcu sayısı artışı \%463'de kalmıştır. Oysa 2004-2015 yılları arasındaki iç hat taşınan yolcu sayısı artışı \%6519 oranına yükselmiştir. Sonuç olarak 2003 yılındaki iç hatlar serbestleşmesinin istenilen sonuçları yarattığ söylenebilir. Bununla birlikte iç hatlar pazarında rekabetin gerçekten artıp artmadığı ve büyümenin iç hatlarda yeni şehir çiftlerinin devreye girmesiyle mi yoksa daha önceden hizmet götürülen şehir çifti pazarlarındaki rekabetin artmasıyla mı oluştuğu araştırmaya değer bir konudur.

\section{Yoğunlaşma ve Pazar Yapıları}

Yoğunlaşma (concentration), herhangi bir piyasada gerçekleştirilen ekonomik faaliyetlerin az sayıda işletme tarafindan yürütülmesi anlamına gelmektedir (Pehlivanoğlu ve Tekçe, 2013, s. 364). Bir başka tanıma göre ise iktisadi kaynaklar ve faaliyetler toplamının az sayıda işletmenin kontrolünde olmasını ifade etmektedir. Bu sebeple rekabet ile piyasa yoğunlaşması arasında ters yönlü bir ilişkinin varlığından söz edilebilir. Yoğunlaşma miktarının yüksek olduğu bir piyasada monopol pazarlar ortaya çıkacak ve dolayısıyla rekabetin azalmasına bağlı olarak fiyatlarda artış gözlenecektir. Bu durum pazardaki mevcut ve potansiyel alıcıları olumsuz yönde etkileyecektir (Durukan ve Hamurcu, 2009, s. 75).

Piyasa yapısı belirlenirken başvurulan birçok yöntem vardır ve piyasa yapılarını belirleme sürecinde yoğunlaşma indeksleri kullanılan araçlar arasındadır (Polat, 2007, s. 99). Pazar yoğunluğu endeksleri, pazar gücünün ölçülmesinde faydalı göstergeler sağlamaktadır ancak ilgili endekslerin maliyet, talep gibi iktisadi değişkenlerle ya da bu değişkenlerde oluşan değişimlerle sistematik bir ilişkisi söz konusu değildir. Bu endeksler pazar bazlı değerler olduklarından dolayı pazardaki bir işletmenin pazar gücünün belirlenmesinde o alanı ilgilendiren başka verilerle birlikte ele alındıklarında fayda sağlamaktadırlar (Durukan ve Hamurcu, 2009, s. 77).

Piyasa yapısının incelenmesiyle, pazarda bulunan satıcılar arasındaki rekabetin derecesine göre pazar yapılarını sınıflandırmak mümkün hale gelmektedir. Söz konusu yapılar tam rekabet piyasaları ile monopol piyasalar arasında değişen bir görünüm arz etmektedir. Tam rekabet piyasalarında pazarda birçok satıcı bulunmakta, homojen bir piyasa görünümü karşımıza çıkmaktadır. Monopol piyasalarda ise tek bir satıcı bulunmaktadır. Günümüz piyasalarına bakıldığında tam rekabet piyasalarına ve monopol piyasalara rastlamak güçtür ve bu sebeple piyasalar bu iki uç piyasa türü arasında bir yerde şekillenirler. Bunlardan bazıları iki satıcının bulunduğu düopol ve fiyatı belirleyici güce sahip birkaç firmanın bulunduğu oligopol ve fiyat üzerinde etkisi bulunmayan çok sayıda firmanın bulunduğu tekelci rekabet piyasalarıdır (Polat, 2007, s. 99). 
Havayolu taşımacılığının, giderek derinleşen ve yayılan serbestleşme uygulamalarına rağmen, oligopol bir piyasa yapısına sahip olduğu belirtilmektedir (Wensveen, 2007:177). Oligopolistik pazarların en belirleyici özelliklerinden birisi de firmaların hamle ve karşı hamleleri arasında yüksek karşılıklı bağımlılık olmasıdır. Bu nedenle havayolu işletmeleri arasında fiyat rekabetinin oldukça düşük olduğu ileri sürülmektedir (Holloway, 2008:215). Bir havayolu işletmesi fiyatlarını düşürdüğünde diğerleri de düşürmek durumunda kalacaklar ve her birisinin birim gelirleri azalacaktır. Sadece birkaç oyuncunun yer aldığ 1 oligopolistik pazarda havayolu işletmeleri bunu bildikleri için fiyat rekabetinden uzak durmaktadır (Hanlon, 2007: 70). Bu nedenle yüksek oligopolistik özellikler taşıyan havayolu pazarlarında fiyat rekabetinin ortaya çıkması çok beklenen bir durum değildir. Buna karşın, havayolu taşımacılığında fiyatın talep elastikiyeti yüksektir ve sektörün büyüyebilmesi için rekabet artışından en fazla beklenen fayda fiyatların düşmesidir. Tam da bu noktada Türkiye iç hatlar havayolu pazarındaki yoğunlaşma derecesinin bilinmesinde fayda olduğu ortaya çıkmaktadır.

Oligopol piyasalarda firma sayısının azlığına bağlı olarak yoğunlaşma derecesinin yüksek olması beklenir. Oligopolistik özellikler taşıyan havayolu taşımacılığı pazarında az sayıda havayolu işletmesi pazar payının büyük bir bölümünü elinde tutmaktadır (Button vd., 1998; Vasigh vd., 2013, s. 253). Diğer yandan oligopol pazarlara girişin önünde önemli engeller bulunmaktadır. Ekonomik düzenleme kapsamındaki pazara giriş engelleri kaldırılsa bile havaalanlarındaki slot uygulamaları, nitelikli insan kaynağı bulmanın güç olması, yatırım ve işletim maliyetlerinin yüksekliği gibi nedenlerle yeni havayolu işletmelerinin kurulması ve pazara girişleri önünde yüksek engeller bulunmaktadır (Vasigh vd., 2013, s. 253).

Genel olarak oligopol piyasaların diğer bir özelliği firmaların üretim miktarını artırarak birim maliyetleri azaltmak anlamına gelen ölçek ekonomilerinden yararlanmalarıdır. Oysa havayolu taşımacılığında üretim miktarı artışı ile birim maliyetlerin azalması arasında herhangi bir ilişki bulunmadığını gösteren araştırmalara rastlanmaktadır (Oum ve Zang, 1997, s.309-314; Crell ve Farell, 2001, s.321-322). Büyük havayolu işletmelerinin küçükler karşısındaki rekabet avantajı ölçek ekonomilerinden değil büyük ve geniş uçuş ağ yapılarına bağlı olarak ortaya çıkan kapsam ekonomilerinden kaynaklanmaktadır (Doganis, 2002, s.136).

\section{Konuyla İlgili Yapılan Çalışmalar}

Piyasa yoğunlaşması ile ilgili yazın incelendiğinde farklı alanlarda farklı yazarların yapmış olduğu pek çok çalışma görülmektedir. Önder (2016) bisküvi, çikolata ve şekerli mamuller sektörü üzerinde yapmış olduğu yoğunlaşma analizi sonucunda ilgili sektörlerin CR4 ve CR8 analizlerine göre yüksek yoğunlaşma değerlerine sahip olduğunu, HHI ve Entropi ve Rosenbluth indeksi sonuçlarına göre ise sektörün monopolcü rekabet ile oligopol arasında yer aldığını belirtmiş̧tir. Kaynak (2016) giyim eşyası imalatı sektöründe 1995-2014 yılları arasında piyasa 
yapısını belirlemek için yapmış olduğu çalışmasında CR8'e göre 2002-2003 yılları haricinde yüksek yoğunlaşma gözlemlendiği, HHI'a göre ise 2008 yılına kadar düşük yoğunlaşma, 2008'den sonra ise orta düzeyde yoğunlaşmanın olduğu sonuçlarına varmıştır. Yang'ın (2016) düşük maliyetli taşıyıcıların havalimanı şehir çiftlerine girişinin havalimanı çifti talebi üzerinde etkisinin bir model üzerinde incelendiği çalışmasında HHI yoğunlaşma değeri düzeyi ve LCC'lerin giriş etkilerinin hat seviyesinde yolcu talebini etkilediği sonucuna ulaşılmıştır. Ayrıca pazara yeni bir LCC'nin girmesiyle ilk 3 ay yolcu talebinin arttığını ve dolayısıyla yoğunlaşma değerinin azaldığını ancak dördüncü aydan itibaren bu etkinin kaybolarak HHI değerinin tekrar arttığını gözlemlemişlerdir. Korkmaz ve arkadaşları (2016) 2007-2014 arasında Bankacılık sektöründe yoğunlaşma ile finansal kırılganlık arasındaki ilişkiyi inceledikleri çalışmalarında yoğunlaşma ve finansal kırılganlık arasında çift yönlü bir etkileşim olduğunu tespit etmişlerdir. Dilek ve Konak (2016) Kastamonu helva üretimi sektöründe 1994-2014 yıllar arasındaki durumu inceledikleri çalışmalarında ilgili sektörde yoğunlaşma değerlerinin zaman içerisinde düştügünü ve 2003 yılı içerisinde oligopolistik özellikler gösteren endüstride son yıllarda rekabetin arttığını gözlemlemişlerdir. Özbek ve Fidan (2016) tarım ilaçları endüstrisinde piyasa yapısını belirlemeye yönelik yapmış oldukları çalışmalarında söz konusu sektörde yüksek yoğunlaşma değerleri ve dolayisıyla oligopol piyasa özelliklerinin bulunduğunu tespit etmişlerdir. Dai ve arkadaşlarının (2014) ABD havacılık endüstrisinde fiyat dağılımı ve rekabeti birlikte incelediği çalışmalarında yoğun olan pazarlarda artan rekabetin fiyat dağılımını arttırdığı ancak rekabetçi piyasalarda daha az fiyat çeşitlemesi olduğu sonucuna ulaşmışlardır. Kiracı ve arkadaşları (2015) Türkiye iç hat havayolu taşımacılığında en büyük 5 havalimanında yapmış oldukları yoğunlaşma analizinde piyasanın rekabetçi bir yapıdan uzak olduğunu sonucuna ulaşmışlardır. Havacılık alanında bir başka çalışmada ise Sarıbaş ve Tekiner (2015) Türk Sivil Havac1lık sektöründe rekabet düzeyinin oligopol özellik gösterdiğini ve yüksek yoğunlaşma derecelerinin THY'nin yüksek pazar payından kaynaklandığını belirtmiş̧tir. Hem Sarıbaş ve Tekiner (2015) hem de Kiracı ve arkadaşları (2015) Türkiye iç hat havayolu taşımacılığını havayolu işletmelerinin ilgili pazar payları üzerinden genel olarak değerlendirmiş ve değerlendirmelerini Türkiye genelinde ve havalimanları temelinde yapmışlardır. Bu çalışmada ise iç hat havayolu taşımacılığı söz konusu çalışmalardan farklı olarak pazar çifti bağlamında değerlendirilerek her bir şehir çifti ayrı bir pazar olarak ele alınacak ve değerlendirmeler pazar çifti temelinde yapılacaktır.

\section{YÖNTEM}

$\mathrm{Bu}$ araştırmada iç hat havayolu taşımacılı̆̆ının şehir çiftleri bazında piyasa yapısını belirlemek amacıyla yoğunlaşma analizine başvurulmuştur. Söz konusu analiz sürecinde piyasa yoğunlaşmasını ölçmek için kullanılan yöntemler incelenmiştir. Bununla ilgili olarak üç yöntem üzerinde ağırlıklı olarak durulmuştur. Çalışmada 2012-2014 yılları arasında iç hatlarda faaliyet gösteren havayolu işletmelerinin taşımış oldukları yolcu sayıları şehir çifti bazında 
incelenerek toplamda 1447 şehir çiftinin piyasa yapısı N firma yoğunlaşma oranı, Herfindahl-Hirschman Endeksi ve Entropi Endeksi ile analiz edilmiştir. Şehir çifti yolcu sayıları verileri 2012 yılından itibaren kayıt altına alınmaya başlanmıştır. Dolayısıyla bu araştırmada veriler 2012-2014 yılları arasını kapsamaktadır.

Endüstri ya da piyasa yoğunlaşmasını ölçmek için kullanılan birçok yöntem vardır. Söz konusu yöntemler içerisinde en çok kullanılanları M-Firma Yoğunlaşma Oranı (M-Firm Concentration Ratio) ve Herfindahl-Hirshcmann Endeksi (HHI Index) yöntemleridir. Bunlar pazar performansı ile yapı-davranışperformans yaklaşımı çerçevesinde kullanılan yöntemlerdir. M-Firma Yoğunlaşma oranı, piyasa yoğunlaşmasını pazarda faaliyet gösteren genellikle dört, sekiz ya da on iki firmanın pazar paylarının toplamı şeklinde ifade etmektedir (Pehlivanoğlu ve Tekçe, 2013, s. 374). M-Firma yoğunlaşma oranı şu şekilde hesaplanmaktadır (Yıldırım ve Eşkinat, 1995, s. 37):

$$
\mathrm{CR}_{\mathrm{M}}=1 / \mathrm{x} \sum_{i \div 1}^{m} X i
$$

$\mathrm{CR}_{\mathrm{M}}$ : M sayıda işletme için yoğunlaşma oranı.

$X i$ : İ firması için $\mathrm{x}$ değişkeninin aldığı değer.

$\mathrm{X}$ : Piyasadaki işletmelerin tümü için $\mathrm{x}$ değişkeninin aldığı toplam değer.

Hesaplama sonucunda oluşan değer 0-100 arasındadır (Süslü ve Baydur, 1999, s. 155) ve yüksek bir yoğunlaşma oranı daha düşük bir rekabete, daha düşük bir yoğunlaşma oranı ise daha yüksek seviyede rekabete işaret etmektedir (Pavic vd., 2012, s. 56). M-Firma yoğunlaşma oranı ile yapılan işlemler sonucunda elde edilecek değerler ve karşıllk geldikleri rekabet seviyeleri aşağıda verilmektedir (Polat, 2007, s. 100):

- $\mathrm{CR}_{\mathrm{M}}<30$ ise düşük derecede yoğunlaşmadan ve rekabetin varlığından söz edilebilir.

- $\quad 30 \leq \mathrm{CR}_{\mathrm{M}}<50$ ise orta derecede bir yoğunlaşma söz konusudur. Rekabet azalmaktadır; tekelci bir rekabet ortamından söz edilebilir.

- $50 \leq \mathrm{CR}_{\mathrm{M}} \leq 70$ ise yüksek derecede bir yoğunlaşma vard1. Rekabet iyice azalmaktadır ve oligopolist bir pazara doğru gidilmektedir.

- $\mathrm{CR}_{\mathrm{M}}>70$ ise çok yüksek derecede bir yoğunlaşma söz konusudur ve Monopol bir piyasa oluşmaktadır.

$\mathrm{CR}_{\mathrm{M}}$ analizleri pazar yoğunlaşmasının ölçülmesinde yaygın olarak kullanılan modeller olmuştur ancak $\mathrm{CR}_{\mathrm{M}}$ analizine yapılan (1) pazarlardaki işletmelerin göreli büyüklüklerini yansıtmaması ve (2) pazarda yer alan firmaların sadece belirli bir bölümünü analiz içine dâhil etmesi gibi eleştirilerle birlikte yerini bir diğer yoğunlaşma ölçüm aracı olan Herfindahl-Hirschmann Endeksi'ne (HHI) bırakmaya başlamışır (Weinstock, 1982, s. 285). Günümüzde yaygın olarak kullanılan HHI, pazarda yer alan her bir işletmenin pazar paylarının karelerinin toplamından oluşan değeri verir ve şu şekilde hesaplanır:

$$
\text { HHI: } \sum_{i: 1}^{n} P i^{2}
$$

HHI: Herfindahl-Hirschmann Endeksi Değeri 
$P i:$ İ inci işletmenin pazar payı

Endeks değeri 0 ile 10.000 arasında değerler almaktadır ve elde edilen değerler aşağıda verilen pazar sınıflandırmalarına işaret etmektedir ( $\mathrm{Su}, 2003$, s. 12):

- $0<\mathrm{HHI} \leq 2000$ yoğun olmayan bir pazar,

- $2001 \leq \mathrm{HHI} \leq 4000$ orta yoğunlukta bir pazar,

- $\quad 4001 \leq \mathrm{HHI} \leq 10000$ yüksek derecede yoğun bir pazar.

Yukarıdaki sınıflandırmadan farklı olarak elde edilecek değerleri 0-1000, $1000-1800$ ve +1800 olarak ya da $0-1500$, 1500-2500 ve +2500 olarak sınıflandıran çalışmalar da mevcuttur (Pehlivanoğlu ve Tekçe, 2013, s. 375).

HHI yoğunlaşma endeksi hem pazarda faaliyet gösteren her bir işletmeyi hem de bu işletmelerin paylarının göreceli durumunu dikkate alır. Hesaplamada pazar paylarının karelerinin alınması piyasaya hâkimiyet açısından pazar payı daha yüksek olan işletmelerin daha ağırlıklı temsil edilmesini sağlamaktadır. Söz konusu sebeplerle bu endeks ilgili pazara/piyasaya dair $\mathrm{CR}_{\mathrm{M}}$ endeksine kıyasla daha bütüncül bir görünüm sağlamaktadır (Weinstock, 1982, s. 287). Ayrıca işletme büyüklükleri arasındaki değişiklikleri dikkate alması ve tüm dağılımın hesaba dâhil edilmesi gibi sebeplerle daha hassas bir ölçüm aracı olarak kabul edilmektedir (Kaynak ve Ar1, 2011, s. 50). Yukarıdaki sebeplerle birlikte, HHI endeksi 1980'lerden günümüze en popüler piyasa belirleme araçlarından biri olmuştur (Polat, 2007, s. 100).

Piyasa yoğunlaşmasını belirlemek için kullanılan bir diğer ölçüm aracı Entropi endeksidir. Entropi endeksi, firmaların pazar paylarındaki eşitsizlikleri, faaliyet gösteren firma sayısını ve bu firmaların büyüklüklerini dikkate alan bir araçtır. Entropi katsayısı, ters yoğunluk ölçümüdür. Bir diğer ifade ile E değeri azaldıkça yoğunlaşma da artacaktır. HHI endeksinden farklı olarak Entropi endeksinde ölçüm sonuçları firmaların göreceli büyüklüklerine daha duyarlıdır. Entropi endeksi firmaların pazar payları ile pazar paylarının logaritmalarının bire bölünmesinden elde edilen değerin çarpımı ile hesaplanmakta ve şu şekilde gösterilmektedir (Önder, 2016, s. 197).

$$
\mathrm{E}: \sum_{i: 1}^{n} \operatorname{si} \cdot \log (1 / \mathrm{si})
$$

Araştırmaya konu olan veriler DHMI Genel Müdürlüğünün istatistik yıllıklarından ve SHGM'den elde edilmiştir. Elde edilen veriler yukarıda açıklanan endeksler yardımıyla analiz edilerek şehir çiftlerinin piyasa yapısı belirlenmiş ve aynı zamanda şehir çiftlerinin yoğunlaşma değerlerine göre frekans analizleri yapılmıştır. Yapılan analizler her bir yıl için ayrı ele alınmış ve sonuçlar hem kendi içerisinde hem de karşılaştırmalı olarak değerlendirilmiştir.

\section{BULGULAR VE YORUMLAR}

Türkiye iç hatlar havayolu taşımacılığında şehir-çifti düzeyinde piyasa yapılarının belirlendiği bu çalışmada N Firma Yoğunlaşma Oranı, HHI ve Entropi Endeksi ölçümleri sonucunda şehir-çiftlerinin piyasa yapıları HHI için 3 ayrı 
kategori olmak üzere incelenerek her bir yıl için ayrı sınıflandırma ve frekans analizleri yapılmıştır.

\section{A. İç Hat Havayolu Taşımacılığına İlişkin İstatistikler}

İç hat havayolu taşımacılığ 1 ile ilgili olarak 2012-2014 yılları arasındaki istatistiklerin yer aldığı bu bölümde Tablo 2'de ilgili yıllara ait taşınan yolcu sayıları ve Tablo 3'de faaliyet gösterilen iç hat pazar sayısına ait bilgilere yer verilmektedir.

Tablo 2. İç Hatlarda Havayolu İşletmelerinin Taşımış Oldukları Yolcu Sayıları

\begin{tabular}{|c|c|c|c|c|c|c|c|c|}
\hline \multirow[b]{3}{*}{$\begin{array}{c}\text { Havayolu } \\
\text { İşletmeleri }\end{array}$} & \multicolumn{8}{|c|}{ İç Hat Yolcu Sayıları ve Pazar Payları } \\
\hline & \multicolumn{2}{|c|}{2012} & \multicolumn{3}{|c|}{2013} & \multicolumn{3}{|c|}{2014} \\
\hline & $\begin{array}{l}\text { Yolcu } \\
\text { Sayısı }\end{array}$ & $\begin{array}{c}\text { Paza } \\
\text { r } \\
\text { Payı } \\
(\%) \\
\end{array}$ & $\begin{array}{l}\text { Yolcu } \\
\text { Sayısı }\end{array}$ & $\begin{array}{c}\text { Pazar } \\
\text { Payı } \\
(\%)\end{array}$ & $\begin{array}{c}2012- \\
13 \\
\text { artiş } \\
(\%)\end{array}$ & $\begin{array}{l}\text { Yolcu } \\
\text { Sayısı }\end{array}$ & $\begin{array}{c}\text { Pazar } \\
\text { Payı } \\
(\%)\end{array}$ & $\begin{array}{c}2013- \\
14 \\
\text { artıs } \\
(\%)\end{array}$ \\
\hline Borajet & 671.861 & 1,2 & 460.730 & $\overline{0,6}$ & $-31,42$ & 655.625 & 0,7 & 42,30 \\
\hline Atlas Global & 3.691 .150 & 6,7 & 4.729 .292 & 6,2 & 28,13 & 4.723 .709 & 5,5 & $-0,12$ \\
\hline Onur Air & 5.282 .311 & 9,6 & 6.272 .085 & 8,2 & 18,74 & 6.098 .701 & 7,1 & $-2,76$ \\
\hline Pegasus & 10.229 .798 & 18,6 & 20.447 .828 & 26,9 & 99,88 & 23.938 .738 & 28 & 17,07 \\
\hline Sun Express & 4.739 .717 & 8,6 & 4.162 .862 & 5,4 & $-12,17$ & 4.395 .227 & 5,1 & 5,58 \\
\hline Anadolu Jet & 9.086 .577 & 16,5 & 15.223 .427 & 20 & 67,54 & 17.206 .697 & 20,1 & 13,03 \\
\hline $\begin{array}{l}\text { Türk Hava } \\
\text { Yolları }\end{array}$ & 21.228 .489 & 38,6 & 24.837 .184 & 32,6 & 17,00 & 28.315 .313 & 33,1 & 14,00 \\
\hline Diğer* & 19200 & 0,2 & 13505 & 0,1 & $-29,66$ & 82156 & $\overline{0,4}$ & 508,34 \\
\hline TOPLAM $^{3}$ & 54.949 .103 & 100 & 76.146 .913 & 100 & 38,58 & 85.416 .166 & 100 & 12,17 \\
\hline
\end{tabular}

*Türkiye'deki havaalanlarında Corendon, Freebird ve Tailwind gibi havayolu işletmeleri tarafından tarifesiz ve charter türü seferlerle taşınan yolcu sayıları.

Kaynak: DHMİ İstatistik Yıllıkları (2012-2014)

Tablo 2'de yer alan verilere göre toplam yolcu sayısında 2012 yılı sonundan 2014 yılsonuna kadar 30 milyondan fazla $(\% 55,4)$ bir artış gerçekleşmiş̧ir. Havayolu işletmelerine tek tek bakıldığında ise yolcu sayılarında düzenli bir artış gözlemlenmemektedir. Bazı havayolu işletmelerinin yolcu sayısı bir önceki yıla göre düşüş gösterip sonraki yıl tekrardan artmış (Borajet ve Sun Express), bazılarında ise ilk olarak artış gözlemlenip bir sonraki yıl düşüş yaşanmıştır (Atlas Global ve Onur Havayolları). Havayolu işletmeleri arasında sadece Pegasus, Anadolu Jet ve Türk Hava Yolları'nın yolcu sayılarında devamlı bir artış gözlemlenmiştir. Bunlar arasında en yüksek artışa sahip havayolu işletmesi olan Pegasus'ta artış 2012-2013 arasında 10,2 milyon $(\% 99,8), 2013$ 2014 arasinda 3,5 milyon $(\% 17,07)$ ve toplamda 13,7 milyon (\%134) olarak gerçekleşmiştir. Türk Hava Yolları'nın iç hat havayolu taşımacılığındaki yolcu sayısındaki artış ise söz konusu yıllar içerisinde daha sabit bir görünüm sergilemiş

\footnotetext{
${ }^{3}$ Türkiye'deki havaalanlarından tarifeli ve tarifesiz seferlerle geçen toplam yolcu sayısını göstermektedir. Bu çalışmaya Corendon, Freebird ve Tailwind gibi tarifesiz sefer düzenleyen havayolu işletmeleri dâhil edilmemiştir.
} 
ve 2012'den 2014 yılsonuna kadar 7,1 milyonluk bir artış yaşanmıştır. Ancak bu artışa rağmen THY'nin iç hat pazar payının giderek düştüğü ve pazar payının diğer havayolu işletmelerine kaydığı görülmektedir.

Tablo 3. Faaliyet Gösterilen İç Hat Şehir Çifti Sayısı

\begin{tabular}{cccccc}
\hline \multicolumn{7}{c}{ İç Hat Şehir Çifti Sayıları (2012-2014) } \\
Havayolu İşletmeleri & $\mathbf{2 0 1 2}$ & $\mathbf{2 0 1 3}$ & $\begin{array}{c}\mathbf{2 0 1 2 - 1 3} \\
\mathbf{a r t ı s ̧ ~ ( \% )}\end{array}$ & $\mathbf{2 0 1 4}$ & $\begin{array}{c}\mathbf{2 0 1 3 - 1 4} \\
\text { artış (\%) }\end{array}$ \\
\hline Borajet & 83 & 134 & 61,45 & 96 & $-28,36$ \\
Atlas Global & 39 & 77 & 97,44 & 78 & 1,30 \\
Onur Havayolları & 44 & 56 & 27,27 & 54 & $-3,57$ \\
Pegasus & 125 & 135 & 8,00 & 149 & 10,37 \\
Sun Express & 99 & 100 & 1,01 & 88 & $-12,00$ \\
Anadolu Jet & 93 & 121 & 30,11 & 148 & 22,31 \\
Türk Hava Yolları & 166 & 228 & 37,35 & 235 & 3,07 \\
\hline TOPLAM & 397 & 520 & 30,98 & 530 & 1,92 \\
\hline
\end{tabular}

Kaynak: DHMİ

Tablo 3'e göre toplam şehir çifti pazar sayısında 2012 ve 2014 yılları arasındaki fark karşılaştırıldığında \%33,5'lik bir artış görülmektedir. Yıllar arasındaki değişim tek tek incelendiğinde ise 2013 yılı sonunda bir önceki yıla göre rekabet edilen pazarlara 123 yeni şehir çifti pazarının (\%30,9'luk artış) eklendiği, 2014 yılı sonunda ise yalnızca 10 yeni şehir çifti pazarının $(\% 1,9)$ eklendiği görülmektedir. Havayolu işletmelerine bakıldığında ise Atlas Global, Pegasus, Anadolu Jet ve Türk Hava Yollarının faaliyet gösterdiği pazar sayılarını önceki yıllara göre artırdığı ve bu artışın düzenli bir biçimde (her yıl artan) gerçekleştiği görülmektedir. Bunlardan THY toplamda faaliyet gösterdiği pazar sayısına 69 yeni pazar daha eklemiş ve pazar sayısında \%41,5'lik bir artış gerçekleşmiştir. Sun Express havayolu işletmesinin faaliyet gösterdiği pazar sayısı 2014 y1lı sonunda önceki yıllara göre azalış göstermiştir. Sun Express'in 2013 dönemi sonunda bir önceki yıla göre pazar sayısına bir yeni şehir çifti daha eklemiş olsa da bir sonraki yıl 12 pazardan çekilerek faaliyet gösterdiği toplam pazar sayısını \%12,5 oranında azaltmıştır. Faaliyet gösterdiği pazar sayısındaki artışın süreklilik göstermediği işletmeler Borajet ve Onur Havayolları'dır. Bu iki havayolu işletmesinin pazar sayıları 2013 yılı sonunda bir önceki yıla göre artış göstermiş ancak 2014 y1lı sonunda 2013'e göre düşüş gerçekleşmiştir. Onur Havayollarının artış ve azalış yüzdeleri görece az olmakla birlikte, Borajetin pazar sayılarında önemli dalgalanmalar görülmektedir.

\footnotetext{
4 Havayolu işletmelerinin faaliyet gösterdiği hatların toplamı ortak pazarları da kapsadığından toplam satırı sadece iç hat pazarında faaliyet gösterilen şehir çifti sayısını vermektedir.
} 


\section{B. N-Firma Yoğunlaşma Oranına Göre İç Hat Havayolu Pazar Çiftlerinin Analizi}

Pazarda yer alan $\mathrm{N}$ sayıda firmanın pazar paylarının toplamı ile elde edilen $\mathrm{N}$-firma yoğunlaşma oranında $\mathrm{N}$ değeri 2, 4, 8, 12 gibi farklı değerler alabilmekte ve bu bağlamda farklı piyasa değerlendirmeleri yapilabilmektedir. Polat'ın (2007) belirttiği üzere, yoğunlaşma 70'in üstünde bir değere sahipse yoğun bir pazardan söz edilmekte, 30'un altında ise bu değer az yoğun bir pazarı işaret etmektedir. 2012-2014 yılları arasında iç hat havayolu taşımacılığındaki şehir çiftleri pazar olarak ele alındığında tüm yıllar için yoğunlaşma değerlerinin hemen hepsinin \%100 olduğu görülmektedir. Bu durumun oluşmasında en önemli etken şehir çiftlerinde faaliyet gösteren havayolu işletmesi sayısının az olmasıdır. Bir diğer etken ise pazara hâkim en az bir ya da iki havayolu işletmesinin pazarın çok büyük bir bölümünü domine etmesidir. Söz konusu durumu daha iyi açıklayabilmek için Tablo 4'te iç hatlardaki şehir çifti pazarlarında kaç havayolu işletmesinin faaliyet gösterdiğine ilişkin bilgiler, Tablo 5'te ise monopol olan pazarlarda hangi havayolu işletmelerinin faaliyet gösterdiğine bir diğer ifade ile monopol pazarların havayolu bazlı dağılımlarına ilişkin bilgilere yer verilmektedir.

Tablo 2. İç Hat Pazarlarında Faaliyet Gösteren Firma Sayılarının Dağılımı

\begin{tabular}{cccc}
\hline Pazar Ciftlerindeki & \multicolumn{3}{c}{ Frekans } \\
\cline { 2 - 4 } Firma Sayıs1 & $\mathbf{2 0 1 2}$ & $\mathbf{2 0 1 3}$ & $\mathbf{2 0 1 4}$ \\
\hline 1 & 219 & 299 & 296 \\
2 & 84 & 122 & 140 \\
3 & 67 & 55 & 56 \\
4 & 20 & 31 & 23 \\
5 & 7 & 11 & 10 \\
6 & - & 1 & 4 \\
7 & - & - & 1 \\
8 & - & 1 & - \\
\hline TOPLAM & 397 & 520 & 530 \\
\hline
\end{tabular}

Tablo 4'teki bilgilere göre 2012 y1lında 397 pazarın 219'unun monopol olduğu görülmektedir $(\% 55,16)$. Geriye kalan 178 pazarın ise 84 'ünde sadece iki havayolu işletmesi faaliyetlerini göstermektedir. Firma sayısı açısından ele alındığında 84 pazar duopol olarak değerlendirilebilir ancak söz konusu pazarlarda yer alan havayolu işletmelerinin pazar payları da hesaba katıldığında duopol pazar sayısının daha da düştügü görülmektedir. 67 pazarda 3 havayolu işletmesinin, 20 pazarda ise 4 havayolu işletmesinin faaliyet gösterdiği görülmektedir. Son olarak 7 şehir çifti pazarında 5 havayolu işletmesi faaliyetlerini gerçekleştirmiştir. N-Firma yoğunlaşma oranları açısından 2012 yılı firma sayıları da düşünülerek değerlendirildiğinde sadece 27 pazarda CR-4 analizi yapmak mümkündür ancak analiz yapıldığında ortaya çıkacak değer sektörün yapısından dolayı 100 ve 100 'e çok yakın değerler olacağından bu analizi yapmak 
yerinde olmayacaktır. Bu sebeple şehir çifti pazarlarında N-Firma yoğunlaşma analizi yapmak pazarın yapısını doğru değerlendirme açısından çok sağliklı olmayacaktır. Analiz yapılan pazarların 390'nında yoğunlaşma değeri 100'dür. Sadece 7 pazarda bu rakamdan farklı sonuçlar elde edilmiş olsa da değerlerin \%99,98-\%99,99 olduğu görülmektedir.

2013 yılı şehir çifti pazarları incelendiğinde 520 pazarın 299'unda sadece tek bir havayolu işletmesinin faaliyet gösterdiği monopol pazar durumunun oluştuğu gözlemlenmiştir $(\% 57,5) .122$ pazarda ise 2 işletme mevcut olup firma sayısı açısından duopol şehir çifti pazarları oluştuğu görülmektedir $(\% 23,46) .55$ şehir çiftinde 3 havayolu işletmesi, 31 pazarda 4 havayolu işletmesi ve 11'inde ise 5 havayolu işletmesi yolcu taşıma işini gerçekleştirmiş̧tir. Son olarak birer pazarda da 6 ve 8 havayolu işletmesi olduğu görülmektedir. Genel bir değerlendirme yapıldığında CR-4 analizinin yapılabileceği pazar sayısı 44, CR-8 analizinin yapılabileceği pazar sayıs1 ise sadece 1'dir. 2012 y1lında olduğu gibi analize sayı olarak elverişli pazarlar varsa bile değerler incelendiğinde CR-4 için 31 pazarda tam yoğunlaşma $(\mathrm{CR}-4=100)$ ve 13 pazarda ise neredeyse tam yoğunlaşma (CR-4 100) durumu gözlemlenmiştir. CR-8 için ise zaten 8 firma sayısına sahip sadece bir pazar bulunmakta ve değerler toplandığında tam yoğunlaşma durumunun oluştuğu görülmektedir (CR-8=100).

2014 yılı verileri incelendiğinde de 530 pazarın 296'sında tek bir firmanın olduğu görülmektedir. Bir diğer ifade ile 2014 yılı iç hat havayolu taşımacılığında faaliyet gösterilen 296 pazar monopoldür $(\% 55,84) .140$ pazar ise daha önce de belirtildiği üzere 'firma sayısı açısından' duopol özellik göstermektedir $(\% 26,41)$. 56 şehir çiftinde 3 havayolu işletmesi, 23'ünde ise 4 havayolu işletmesi faaliyetlerini gerçekleştirmiştir. 10 şehir çiftinde 5 havayolu işletmesi, 4 pazar çiftinde 6 ve son olarak 1 şehir çiftinde 7 havayolu işletmesi olduğu görülmektedir. CR-4 açısından ele alındığında 38 şehir çifti pazarı analiz teknik olarak yapılabilmektedir ancak daha önceki y1llarda görülen yoğunlaşma değerleri bu y1l için de gözlemlenmektedir (23 pazar çifti için: CR-4=100; 15 pazar çifti için: CR-4 100).

Tablo 5'te 2012-2014 y1lları arasında verilen firma sayılarına ek olarak monopol pazarların havayolu işletmelerine göre dağılımı görülmektedir.

Tablo 3. Monopol Pazar Çiftlerinin Havayolu İşletmelerine Göre Dağılımı

\begin{tabular}{cccc}
\hline & \multicolumn{3}{c}{ Yıllara Göre Monopol Pazar Sayları } \\
\hline & $\mathbf{2 0 1 2}$ & $\mathbf{2 0 1 3}$ & $\mathbf{2 0 1 4}$ \\
\hline Borajet & 49 & 60 & 32 \\
Atlas Global & 2 & 7 & 5 \\
Onur Air & 2 & 5 & 6 \\
Sun Express & 20 & 21 & 19 \\
Anadolu Jet & 29 & 38 & 57 \\
Pegasus & 21 & 28 & 24 \\
Türk Hava Yolları & 87 & 133 & 141 \\
Diğer & 9 & 7 & 12 \\
\hline TOPLAM & 219 & 299 & 296 \\
\hline
\end{tabular}


Tablo 5'teki veriler incelendiğinde 2012 yılında gözlemlenen 219 pazarın 87'sinde Türk Hava Yolları'nın monopol olduğu görülmektedir $(\% 39,72)$. Türk Hava Yolları'nı 49 pazar ile Borajet takip etmektedir (22,37). Sun Express ve Pegasus'un sahip olduğu monopol pazar sayısı birbirine oldukça yakındır. 219 pazarın 9'unun yukarıda listede yer almayan tarifesiz havayolu işletmelere ait olduğu bilinmektedir. 2013 yılına ait veriler incelendiğinde 299 monopol pazarın 133'ünde Türk Hava Yolları faaliyet göstermekteyken $(\% 44,48)$ onu 60 pazarla Borajet takip etmektedir $(\% 20,06)$. Anadolu jet monopol pazarlar içerisinde 38 'inde yer almaktayken $(\% 12,70)$ Pegasus 28'inde $(\% 9,36)$ yer almaktadır. 2014 yılı ele alındığında ise 296 monopol pazarda Türk Hava Yolları'nın 141'inde yer aldığı $(\% 47,63)$, THY'yi 57 pazarla Anadolu jet'in takip ettiği $(19,25)$ görülmektedir.

N Firma yoğunlaşma oranına göre yapılan analizler sonucunda piyasanın monopol ve monopole yakın piyasa özellikleri gösterdiği görülmektedir. 2003 yılı iç hat pazarına yönelik düzenlemeler her ne kadar pazara girişin önündeki engelleri kaldırmış ve birden fazla havayolu işletmesinin pazarda faaliyet göstermesinin önü açılmış olsa da pazar çiftleri bakımından değerlendirildiğinde pazarların büyük bir bölümünde halen rekabetten uzak bir görünüm ortaya çıkmıştır.

\section{Herfindahl-Hirschman Endeksine Göre İç Hat Havayolu Pazar Çiftlerinin Analizi}

2012 ve 2014 yılları arasında Türkiye iç hatlar havayolu taşımacılığında faaliyet gösteren havayolu işletmelerinin şehir çifti pazarlarında taşımış oldukları yolcu sayıları temel alınarak yapılan yoğunlaşma analizlerine ilişkin veriler Tablo 6 'da verilmektedir.

Tablo 4. İç Hat Şehir Çifti Pazarlarının Yoğunlaşma Değeri Aralıkları

\begin{tabular}{ccccc}
\hline Piyasa Türleri & Değer Aralıkları & $\mathbf{2 0 1 2}$ & $\mathbf{2 0 1 3}$ & $\mathbf{2 0 1 4}$ \\
\hline \multirow{2}{*}{ Yoğun Olmayan Pazarlar } & $0-1000$ & - & - & - \\
& $1001-2000$ & - & - & - \\
\hline \multirow{2}{*}{ Orta Yoğunlukta Pazarlar } & $2001-3000$ & 2 & - & 1 \\
& $3001-4000$ & 5 & 12 & 9 \\
\hline \multirow{5}{*}{ Yoğun Pazarlar } & $4001-5000$ & 21 & 22 & 26 \\
& $5001-6000$ & 60 & 74 & 73 \\
& $6001-7000$ & 14 & 25 & 30 \\
& $7001-8000$ & 12 & 11 & 9 \\
& $8001-9000$ & 19 & 19 & 13 \\
& $9001-10000$ & 287 & 357 & 369 \\
\hline
\end{tabular}

HHI analizine göre 2012 yılında faaliyet gösterilen 397 şehir çiftinin 390 '1 yoğun pazarlar olarak belirlenmiştir $(\% 98,23)$. 390 pazar frekans analizine göre değerlendirildiğinde ise 287 pazarın 9001-10000 değerleri arasında yer aldığ 1 görülmektedir. 2013 yllına ait veriler incelendiğinde ise 520 pazarın 508'inin 
yoğun pazarlar olduğu görülmektedir $(\% 97,69)$. Yoğun pazarlar içerisinde yer alan 357 şehir çifti pazarında ise değerler monopol olarak nitelendirilen 900110000 aralığındadır. 2014 yılı ele alındığında ise bir önceki yıllarla benzer bir durum gözlemlenmekte ve faaliyet gösterilen 530 şehir çiftinin 520'sinde değerlerin yoğun pazarları işaret ettiği görülmektedir $(98,11)$. Söz konusu yıllar içerisinde iki taşıyıcının pazarın büyük bir bölümüne hâkim olduğu durumlar da gözlemlenmektedir. Bunlardan 2012 y1lı içerisinde 81 şehir çifti (4001-5000: 21; 5001-6000: 60), 2013 y1lı içerisinde 96 şehir çifti ve 2014 yılında da 99 şehir çifti pazarı iki taşıyıcının egemen olduğu şehir çifti sayısı olarak karşımıza çıkmaktadır. Bu analizler sonucunda Türkiye iç hat havayolu taşımacılığında pazarların büyük bir bölümünün monopol ve monopole yakın özellikler gösterdiği ve bir bölümünün de duopol olduğu görülmektedir. Dolayısıyla her ne kadar 2003 yılındaki pazara girişin önünü açan serbestleşme uygulanmasının rekabeti arttırdığı düşüncesi yaygınlaşmış olsa da 2012-2014 yılları aralığında söz konusu piyasanın rekabetten uzak olduğu görülmektedir. Yapılan analizler sonucunda şehir çiftlerinin frekans aralığı aradaki farkın daha iyi anlaşılması açısından Grafik 1'de sunulmuştur.

\section{Şekil 1. 2012-2014 Yılları Arasındaki Yoğunlaşma Grafiği}

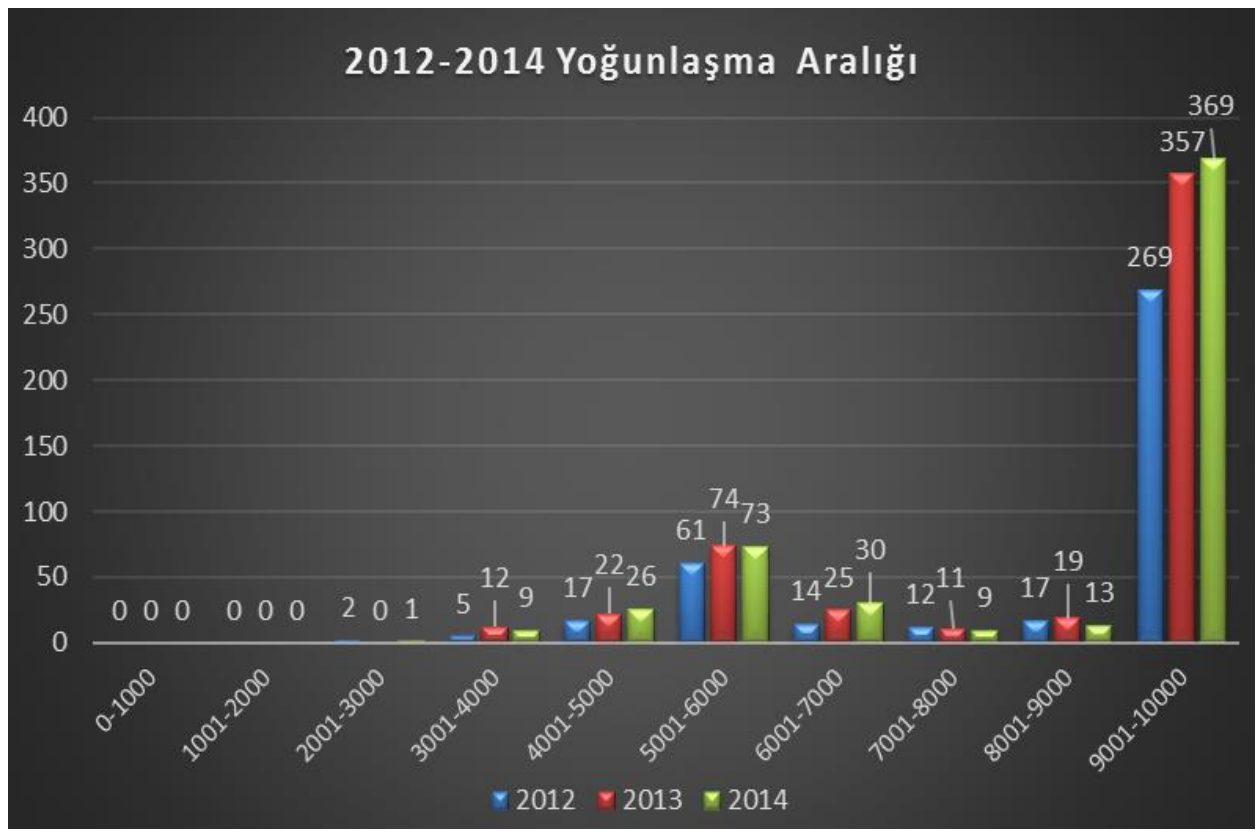

Grafik 1'de yer alan bilgilere göre açıkça görülmektedir ki şehir çifti pazarlarının çok büyük bir bölümünde monopol ve monopole yakın piyasa özellikleri görülmektedir. Monopol pazarları ise 5001-6000 aralığında görüldüğü üzere duopol pazarlar takip etmektedir. Grafikte de açıç̧a görüldüğü üzere hiçbir 
yılda yoğun olmayan pazar yapısı ortaya çıkmamıştır. Ek olarak orta yoğunlukta pazarlar da sayıca çok küçük değerlerdedir.

\section{Entropi Endeksine Göre İç Hat Havayolu Pazar Çiftlerinin Analizi}

Entropi endeksinde pazar payları ile pazar paylarının logaritmaları çarpımı sonucu elde edilen toplam değer pazarın yapısı hakkında bilgi vermektedir. Hesaplamalar sonucunda endeks değeri 0 ile logaritma $n$ (n: pazardaki firma sayısı) arasında bir değer almaktadır. Bu sebeple Entropi endeksi pazardaki mevcut rakiplerin sayısına bağlı olarak değişim gösterebilmektedir. 0 değeri ilgili pazarda tek bir firmanın olduğu monopol pazarları işaret etmektedir. Hesaplamalar sonucunda elde edilen değerler sıfıra yaklaştıkça pazar monopol pazar özelliği göstermeye başlayacak, tersi durumda da pazar oligopol ve rekabetçi pazar özelliği gösterecektir. Böylelikle Entropi endeksinin diğer yoğunlaşma ölçümlerine göre ters bir işleyişinin olduğu ortaya çıkmaktadır. Bir diğer ifadeyle yoğunlaşma ile Entropi değeri arasında ters yönde ilişki söz konusudur. Tablo 7'de faaliyet gösterilen havayolu pazarlarında değişen havayolu işletmesi sayılarına göre Entropi değerlerinin alacağı aralıklar ve yıllara göre şehir çifti pazarlarında minimum ve maksimum Entropi değerleri verilmektedir. Endeks değeri firma sayısı ile ilişkili olduğundan analiz sonuçları şehir çiftlerinde faaliyet gösteren havayolu sayısı ile ilişkili olarak değerlendirilecektir.

Tablo 5. İç Hat Şehir Çifti Pazarlarında Yıllar Göre Entropi Yoğunlaşma Değerleri

\begin{tabular}{|c|c|c|c|c|c|}
\hline \multirow{2}{*}{$\begin{array}{l}\text { Firma } \\
\text { Sayısı } \\
\end{array}$} & \multirow{2}{*}{$\begin{array}{l}\text { Değer Aralığ } \\
\text { '0 } \leq \mathbf{x} \leq \text { Logn' }\end{array}$} & \multicolumn{4}{|c|}{ Yıllara Göre Maksimum ve Minimum Değerler } \\
\hline & & & 2012 & 2013 & 2014 \\
\hline \multirow{2}{*}{1} & \multirow{2}{*}{0} & Min & 0 & 0 & 0 \\
\hline & & Max & 0 & 0 & 0 \\
\hline \multirow{2}{*}{2} & \multirow{2}{*}{$0<\mathrm{x} \leq 0,3010$} & Min & 0,0005 & 0,0005 & 0,00005 \\
\hline & & Max & 0,3010 & 0,3010 & 0,3010 \\
\hline \multirow{2}{*}{3} & \multirow{2}{*}{$0<\mathrm{x} \leq 0,477$} & Min & 0,0049 & 0,0010 & 0,0052 \\
\hline & & Max & 0,4603 & 0,4720 & 0,4596 \\
\hline \multirow{2}{*}{4} & \multirow{2}{*}{$0<x \leq 0,6020$} & Min & 0,0067 & 0,0194 & 0,0073 \\
\hline & & Max & 0,5974 & 0,5429 & 0,5350 \\
\hline \multirow{2}{*}{5} & \multirow{2}{*}{$0<\mathrm{x} \leq 0,6989$} & Min & 0,0068 & 0,1605 & 0,0154 \\
\hline & & Max & 0,6807 & 0,5160 & 0,4901 \\
\hline \multirow{2}{*}{6} & \multirow{2}{*}{$0<\mathrm{x} \leq 0,7780$} & Min & - & 0,3743 & 0,2549 \\
\hline & & Max & - & 0,3743 & 0,6972 \\
\hline \multirow{2}{*}{7} & \multirow{2}{*}{$0<\mathrm{x} \leq 0,8450$} & Min & - & - & 0,4625 \\
\hline & & Max & - & - & 0,4625 \\
\hline \multirow{2}{*}{8} & \multirow{2}{*}{$0<\mathrm{x} \leq 0,9030$} & Min & - & 0,3732 & - \\
\hline & & Max & - & 0,3732 & - \\
\hline
\end{tabular}

Tablo 7'ye göre tek bir havayolu işletmesinin faaliyet gösterdiği şehir çifti pazarlarında Entropi değerinin sıfira eşit olduğu görülmektedir. Tablo 4'ten hatırlanacağı üzere 2012 yılında 219, 2013 y1lında 299 ve 2014 y1lında 296 şehir çiftinin monopol olduğu sonucu elde edilmişti. Bu sebeple söz konusu y1llar içerisinde ilgili pazarların Entropi Endeks değerlerinin sıfira eşit olduğu bulgusu 
elde edilmiştir. Sadece faaliyet gösterilen firma sayısıyla ortaya çıkarılan ve Tablo 4'te verilen durum, Tablo 7'de verilen Entropi Endeksi ölçüm değerleriyle de desteklenmiştir.

2 havayolu işletmesinin faaliyet gösterdiği pazarlarda Entropi değerinin 0 ile 0,301 arasında olması beklenmektedir. 2012 ve 2013 yıllarına göre analiz sonuçları incelendiğinde minimum Entropi değerinin 0,0005 olduğu görülmektedir. Bu bulgu bize şehir çiftlerinde 2 firma olsa bile bunlardan birinin pazar payının çok yüksek olduğunu ve pazar yapısının neredeyse monopole yaklaştığını göstermektedir $\left\{\left(2013 \mathrm{VAN}^{-E_{S B}}{ }^{5}=\mathrm{AJA}: 99,96 \text {; BRJ:0,04 }\right)^{6}(\mathrm{MQM}-\right.$ $\mathrm{ADB}^{7}=$ PGT:99,96; SXS: 0,04) $\}^{8}$. Ayrıca 2014 yılı minimum Entropi değerinin daha da düştüğü ve 0,00005 seviyelerinde indiği görülmektedir. Dolayısıyla daha önceki yıllarda ortaya çıkan monopole yakın piyasa özelliklerinin monopole daha da yaklaştığı ortaya çıkmıştır. Maksimum Entropi değerine bakıldığında da her bir yıl için değerin 0,3010 civarında olduğu ve bu bulgunun şehir çiftlerinde pazar payları birbirlerine yakın havayolu işletmeleri olduğu sonucuna ulaştırmıştır. \{(2014 ADA-ADB ${ }^{9}=$ PGT: 50,45; SXS: 49,55 ve Entropi 2014 ADA-ADB: 0,301012)(2014 IST-DIY ${ }^{10}=$ OHY:45,58; THY: 54,12 ve Entropi 2014 IST-DIY: $0,299332)\}$.

3 havayolu işletmesinin faaliyet gösterdiği şehir çifti pazarlarında Entropi değerlerinin 0 ile 0,477 arasında olması beklenmektedir. Buna göre 2013 yılı sonunda 2012'ye göre yoğunlaşma miktarı artan minimum ve maksimum Entropi değerlerinin 2014 yılı sonunda bir önceki yıla göre tekrardan arttı̆̆ 1 ve monopol özelliğini çok az miktarlarda da olsa yitirdiği görülmektedir. 3 havayolu işletmesinin faaliyet gösterdiği pazarlar incelendiğinde 2 havayolu işletmesinin faaliyet gösterdiği pazarlarda oluşan durumların benzerlerinin bu pazarlar için de oluştuğu görülmektedir. Buna göre bazı pazarlarda firma sayısı birden fazla olmasına rağmen birinin pazarı domine ettiği görülmekteyken (2014 EDO-ESB ${ }^{11}$ = BRJ: 98,76; SXS: 0,56; THY: 0,66 ve Entropi Değeri=0,032534) bazılarında ise görece dengeli bir dağılım görülmektedir (2014 AYT-IST= KKK:27,57; OHY:22,48; THY:49,94 ve Entropi Değeri=0,450595)..$^{12} 4$ havayolu işletmesinin faaliyet gösterdiği pazarlar incelendiğinde Entropi değerinin 0 ile 0,6020 arasında değerler alması beklenmektedir. 4 havayolu işletmesinin bu şehir çifti pazarlarında faaliyet göstermesine rağmen pazarı domine eden firmaların olduğu görülmektedir (2014 ESB-TZX ${ }^{13}=$ AJA: 98,75; BRJ: 0,72; PGT: 0,44; SXS: 0,06 ve Entropi Değeri=0,03353). Pazar paylarının tam olarak dengeli dağılmadığı ve

\footnotetext{
${ }^{5}$ Van Havalimanı-Ankara Esenboğa Havalimanı

${ }^{6}$ Havayolu İşletmelerinin ICAO Kodları: BRJ: Bora jet, AJA: Anadolu Jet

${ }^{7}$ Mardin Havalimanı-İzmir Adnan Menderes Havalimanı

${ }^{8}$ ICAO kodları: PGT: Pegasus, SXS: Sun Express

${ }^{9}$ Adana Şakir Paşa Havalimanı-İzmir Adnan Menderes Havalimanı

${ }^{10}$ İstanbul Atatürk Havalimanı-Diyarbakır Havalimanı

${ }^{11}$ Balıkesir (Edremit) Koca Seyit Havalimanı-Ankara Esenboğa Havalimanı

${ }^{12}$ ICAO kodları: KKK: Atlas Global, OHY: Onur Havayolları, THY: Türk Havayolları

${ }^{13}$ Ankara-Esenboğa Havalimanı-Trabzon Havalimanı
} 
söz konusu pazarlar içerisinde en dengeli dağılımın IST-ADB pazarına ait olduğu görülmektedir (2014 IST-ADB = THY:50,77; KKK:17,40; PGT:17,35; OHY:14,46 ve Entropi Değeri=0,53507).

Şehir çifti sayısının daha az olduğu pazarlardan 5 havayolunun faaliyet gösterdiği şehir çiftlerinde benzer durumların meydana geldiği ve AYT-ADA ${ }^{14}$ şehir çifti pazarının 5 havayolunun faaliyet gösterdiği tüm pazarlar içerisinde en dengeli dağılıma sahip pazar olduğu görülmektedir (2014 AYT-ADA= PGT:57,19; SXS:25,18; KKK:10,69; FHY:5,30; TWI ${ }^{15}: 1,62$ ve Entropi Değeri= 0,451043). 6 havayolu işletmesinin faaliyet gösterdiği pazarlara bakıldığında 2013 y1lında sadece 1 şehir çifti, 2014 y1lında ise 4 şehir çiftinde 6 havayolu işletmesinin sefer düzenlediği görülmektedir. Buna göre $\mathrm{BJV}^{-\mathrm{ADB}^{16}}$ pazar1 Entropi Endeksi ölçümlerine göre en rekabetçi pazar olarak görülmektedir (2014 BJV-ADB= THY:30,08; SXS:24,61; PGT:22,26; OHY:10,59; KKK:9,52; $\mathrm{CAI}^{17}: 2,90$ ve Entropi Değeri= 0,69726). Son olarak 7 havayolu işletmesi sadece 2014 yılında tek bir pazarda aynı anda faaliyet göstermiş (Entropi değeri= 0,4625); 8 havayolu işletmesi ise sadece 2013 yılında tek bir pazarda aynı anda faaliyet göstermiştir (Entropi Değeri=0,3732).

HHI ve N Firma yoğunlaşma oranından farklı olarak firma sayısına ve görece pazar payı küçük olan firmaların pazar paylarını daha hassas bir şekilde ele alan Entropi yöntemiyle iç hatlarda mevcut durum analiz edilmiştir. HHI ve N Firma yoğunlaşma analizlerinde belirlenemeyen piyasa yapısı bu yöntemle belirlenmeye çalışılmıştır. Buna göre monopol olmayan şehir çifti pazarlarının büyük çoğunluğunda havayolu işletmesi sayısı 4-5 olsa bile pazara hakim bir ya da iki havayolu işletmesinin var olduğu sonucu ortaya çıkmıştır. Entropi yöntemi ile elde edilen bulgular bize dengeli dağılan pazarların da olduğunu göstermektedir ancak bunların tüm pazarlar içerisindeki payı istisna olarak değerlendirilecek miktardadır. Genel bir değerlendirme yapıldığında Entropi yöntemi ile elde edilen bulgular sonucunda pazar çiftlerinin çok büyük bir bölümünün rekabetten uzak olduğunu söylemek mümkündür. Dolayısıyla 2003 iç hat serbestleşmesinden sonra yolcu sayılarında meydana gelen yüksek oranlardaki artışın rekabtten daha ziyade pazar sayısının artması ile açıklanması daha doğru olacaktır. Kuşkusuz ilgili yıllar içerisinde 2012 yılı sonunda 397 olan toplam pazar sayısının 2014 yılı sonunda 530'a yükselmesi de bu yargıyı destekler niteliktedir.

\section{E. Önemli Pazarların Farklı Yoğunlaşma Ölçüleri ile Karşılaştırılması}

Şehir çifti pazarlarında başlangıç-varış noktalarının demografik özellikleri ve söz konusu noktalar arasında taşınan yolcu sayıları göz önünde bulundurularak

\footnotetext{
${ }^{14}$ Antalya Uluslararası Havalimanı-Adana Şakir paşa Havalimanı

15 Tailwind Havayolları

${ }^{16}$ Bodrum-Milas Havalimanı-İzmir Adnan Menderes Havalimanı

${ }^{17}$ Corendon Havayolları
} 
belirlenen önemli pazarların farklı yoğunlaşma ölçülerine göre karşılaştırılması Tablo 8'de verilmektedir.

Tablo 6. Önemli Pazarların Yoğunlaşma Değerleri

\begin{tabular}{|c|c|c|c|c|c|c|c|c|c|}
\hline \multirow{2}{*}{$\begin{array}{l}\text { Şehir } \\
\text { Çiftleri }\end{array}$} & \multicolumn{3}{|c|}{ CR4 } & \multicolumn{3}{|c|}{ HHI } & \multicolumn{3}{|c|}{ ENTROPI } \\
\hline & 2012 & 2013 & 2014 & 2012 & 2013 & 2014 & 2012 & 2013 & 2014 \\
\hline ADB-IST & 99,99 & 100 & 100 & 3007 & 3299 & 3413 & $\begin{array}{c}0,5614 \\
(5)\end{array}$ & $\begin{array}{c}0,5417 \\
\text { (4) }\end{array}$ & $\begin{array}{c}0,5334 \\
\text { (4) }\end{array}$ \\
\hline AYT-IST & 100 & 100 & 100 & 3585 & 3680 & 3760 & $\begin{array}{c}0,4617 \\
\text { (4) }\end{array}$ & $\begin{array}{c}0,4565 \\
\text { (4) }\end{array}$ & $\begin{array}{c}0,4505 \\
\text { (3) }\end{array}$ \\
\hline ESB-IST & 100 & 100 & 100 & 9997 & 9995 & 9998 & $\begin{array}{c}0,0005 \\
\text { (2) }\end{array}$ & $\begin{array}{c}0,0010 \\
\text { (2) }\end{array}$ & $\begin{array}{c}0,0002 \\
\text { (2) }\end{array}$ \\
\hline AYT-SAW $^{18}$ & 100 & 99,99 & 99,99 & 5024 & 5146 & 4358 & $\begin{array}{c}0,3752 \\
\text { (4) }\end{array}$ & $\begin{array}{c}0,3743 \\
(6)\end{array}$ & $\begin{array}{c}0,4625 \\
\text { (7) }\end{array}$ \\
\hline ADB-SAW & 100 & 100 & 99,99 & 4670 & 4999 & 4583 & $\begin{array}{c}0,3964 \\
\text { (3) }\end{array}$ & $\begin{array}{c}0,3756 \\
\text { (4) }\end{array}$ & $\begin{array}{c}0,4126 \\
(5)\end{array}$ \\
\hline ESB-SAW & 99,9 & 99,99 & 99,99 & 4280 & 3610 & 3760 & $\begin{array}{c}0,4031 \\
(5)\end{array}$ & $\begin{array}{c}0,4605 \\
(5)\end{array}$ & $\begin{array}{c}0,4523 \\
(5)\end{array}$ \\
\hline ADA-IST & 100 & 100 & 100 & 6200 & 4356 & 4456 & $\begin{array}{c}0,2475 \\
\text { (3) }\end{array}$ & $\begin{array}{c}0,4130 \\
\text { (3) }\end{array}$ & $\begin{array}{c}0,4077 \\
\text { (3) }\end{array}$ \\
\hline ADA-SAW & 100 & 100 & 100 & 4779 & 6009 & 6565 & $\begin{array}{c}0,3879 \\
\text { (3) }\end{array}$ & $\begin{array}{c}0,2774 \\
\text { (4) }\end{array}$ & $\begin{array}{c}0,2636 \\
\text { (4) }\end{array}$ \\
\hline ADB-ESB & 100 & 100 & 100 & 5313 & 5553 & 5462 & $\begin{array}{c}0,2873 \\
\text { (2) }\end{array}$ & $\begin{array}{c}0,2767 \\
\text { (3) }\end{array}$ & $\begin{array}{c}0,2817 \\
\text { (4) }\end{array}$ \\
\hline TZX-SAW & 100 & 99,99 & 100 & 5090 & 5536 & 5537 & $\begin{array}{c}0,3696 \\
\text { (4) }\end{array}$ & $\begin{array}{c}0,3072 \\
(5)\end{array}$ & $\begin{array}{c}0,2929 \\
\text { (3) }\end{array}$ \\
\hline TZX-IST & 100 & 100 & 100 & 5121 & 5339 & 5532 & $\begin{array}{c}0,2967 \\
\text { (3) }\end{array}$ & $\begin{array}{c}0,2860 \\
\text { (2) }\end{array}$ & $\begin{array}{c}0,2774 \\
\text { (2) }\end{array}$ \\
\hline BJV-SAW & 100 & 100 & 99,99 & 4570 & 5665 & 4758 & $\begin{array}{c}0,4336 \\
\text { (4) }\end{array}$ & $\begin{array}{c}0,3455 \\
\text { (4) }\end{array}$ & $\begin{array}{c}0,4052 \\
\quad(5)\end{array}$ \\
\hline BJV-IST & 100 & 100 & 100 & 4223 & 4409 & 4553 & $\begin{array}{c}0,4110 \\
\text { (3) }\end{array}$ & $\begin{array}{l}0,4041 \\
\text { (3) }\end{array}$ & $\begin{array}{c}0,3952 \\
\text { (4) }\end{array}$ \\
\hline GZT-IST $^{19}$ & 100 & 100 & 100 & 6657 & 4225 & 4165 & $\begin{array}{c}0,2252 \\
\text { (3) }\end{array}$ & $\begin{array}{c}0,4214 \\
\text { (3) }\end{array}$ & $\begin{array}{c}0,4251 \\
\text { (3) }\end{array}$ \\
\hline
\end{tabular}

Tablo 7'de yer alan bilgilere bakıldığında CR4 yoğunlaşma analizine göre önemli pazarların tamamında CR4 değerlerinin maksimum veya maksimuma çok yakın değerlere ulaştığı görülmektedir. Ancak bu rakamlar bize pazarların yapısına ilişkin yeterli bilgi sunmamaktadır. Örneğin ADB-IST pazarında 2014 y1lında ortaya çıkan 100 değerinin tek bir firmadan mı yoksa birden fazla firmadan mı kaynaklandığ havayolu işletmesi yer alabilir fakat taşınan yolcuların büyük bir bölümünü tek bir işletme taşıyor, başka bir deyişle pazarı tek başına domine ediyor olabilir. Ayrıca CR4 analizinde firmaların ayrı ayrı pazar paylarına dair bir bilgiye de ulaşmak mümkün değildir. Söz konusu pazardaki değer bir havayolu işletmesinin pazara

\footnotetext{
${ }^{18}$ Antalya Uluslararası Havalimanı-İstanbul Sabiha Gökçen Havalimanı

${ }^{19}$ Gaziantep Havalimanı-İstanbul Atatürk Havalimanı
} 
hâkim olup diğerlerinin çok küçük paylara sahip olması sonucu ortaya çıkabileceği gibi havayolu işletmelerinin pazar paylarının dengeli bir biçimde dağılmış olmasıyla da elde edilebilir. Bu sebeple söz konusu pazarlarda diğer ölçüm araçlarının sunduğu bulguları da değerlendirmekte fayda vardır. Aynı pazar için bakıldığında HHI ve Entropi değerlerine göre pazarın rekabetçi bir yapıda olduğu ve birden fazla işletmenin faaliyet gösterdiği görülmektedir. 2014 yılında 4 havayolu işletmesinin faaliyet gösterdiği ADB-IST hattında Entropi değerinin logaritma 4 değerine yakın değerlerde olduğu görülmektedir. $\mathrm{Bu}$ sebeple havayolu işletmelerinin pazar payları Entropi değerleri düşünüldüğünde dengeli bir dağılım göstermektedir. Önemli pazarlarda sadece ESB-IST hattında bir havayolu işletmesinin çok baskın olduğu görülmektedir. ESB-IST hattının HHI değerlerine bakıldığında değerin neredeyse üst sinır 10000 değerinde olduğu görülmektedir. Bu bulgu bize o pazarda bir havayolu işletmesinin pazar payının \%100'e yakın olduğunu göstermektedir. Tarifeli seferler düşünüldüğünde sadece Türk Hava Yollarının ilgili hatta seferlerinin olduğu bilinmektedir. Normal şartlarda 10000 olması gereken değerin 9995-98 civarında olmasının nedeninin o pazarda birkaç tarifesiz sefer düzenlenmesi sonucu ortaya çıtı̆̆ı söylenebilir. ESB-IST pazarının Entropi değerleri incelendiğinde de HHI analizleri sonucu elde edilen bulguların desteklendiği ve değerlerin monopol pazarı işaret eden 0 değerine çok yakın seviyelerde olduğu görülmektedir. Genel olarak bakıldığında ise önemli pazarlarda ESB-IST Pazarı dışında oligopol pazar yapılarının var olduğunu söylemek mümkündür. Ek olarak ADB-IST ve AYT-IST pazarlarında birden fazla oyuncunun birbirlerine yakın pazar payları ile faaliyetlerini gösterdiği görülmektedir. Diğer önemli şehir çiftlerinde pazar payları düşünülerek genelde 2 oyuncunun pazarın geneline hâkim olduğu duopol pazar yapısının varlığından söz etmek mümkündür.

İç hat havayolu taşımacılığı pazarının önemli bir bölümünü oluşturan söz konusu pazarlarda yapılan analizler sonucunda N Firma yoğunlaşma oranına göre tüm pazarlar çok yoğun olup rekabetten uzaktır ve monopol pazar özellikleri göstermektedir. Bir diğer yöntem HHI'a göre ise ESB-IST pazarı dışında önemli pazarlarda birden fazla işletme vardır ve en az ikisinin pazar payları birbirlerine yakın seviyelerdedir. Entropi yöntemine göre ise önemli pazarlarda $\mathrm{HHI}$ 'da olduğu gibi ESB-IST dışında pazar yapısı oligopoldür. Bir diğer ifade ile az sayıda ancak pazara hâkimiyet açısından birbirlerine yakın firmalar pazarda faaliyetlerini gerçekleştirmektedir. Entropi endeksinin bize sağladığı firma sayıları sayesinde ilgili pazarlardaki firma sayıları bilinebilmektedir. 2012-2014 dönemi içerisinde iç hatlarda 7 havayolu işletmesinin tarifeli olarak sefer yaptığ 1 düşünüldüğünde 'kaymak pazar' olarak da nitelendirilen ve yolcu sayısı ve talep bakımından yüksek seviyelerde seyreden bu pazarların hemen hiçbirinde (2014 AYT-SAW hariç) aynı anda tüm havayolu işletmelerinin sefer yapmıyor olması ve faaliyet gösteren havayolu işletmesi sayısının 3 ile 5 arasında değişmesi ve toplam nüfusu 20 milyonu aşan iki önemli şehri kapsayan ESB-IST pazarının monopol olması dikkat çekici bulgulardır. $\mathrm{Bu}$ durumun ortaya çıkmasında 
THY'nin İstanbul Atatürk, PGT'nin İstanbul Sabiha Gökçen, SXS'nin Antalya ve İzmir Adnan Menderes, AJA'nın Ankara Esenboğa Havalimanlarını üs (base) olarak kullanması ve bu sebeple havayolu işletmelerinin faaliyet gösterdiği şehir çiftlerinin farklılık göstermesi gösterilebilir. Örneğin İstanbul-Ankara şehirleri için düşünüldüğünde THY'nin Atatürk Havalimanı PGT'nin ise Sabiha Gökçen Havalimanını kullandığı bilinmekte ve söz konusu şehir çiftinde IST-ESB ve SAW-ESB pazar çiftleri oluşmaktadır. Sonuç olarak farklı havalimanlarından gerçekleştirilen seferler ve farklı üsler yoğunlaşma değerlerini etkilemekte ve dolayisıyla rekabet azalmaktadır.

\section{SONUC}

1983 y1lında yürürlüğe giren 2920 sayılı Sivil Havacılık Kanunu gereğince 1984 yılında SHY6A adıyla yapılan yönetmelik sivil havayolu işletmelerinin kurulmasına imkân vererek pazara girişin önündeki en büyük engeli kaldırmıştır. Amaç daha fazla Türk tescilli havayolu işletmesinin pazarda rol almasını, gerek yabancı havayolu işletmeleri ile gerekse kendi aralarındaki rekabetin artırılmasını sağlayarak talebin ve sistemin büyütülmesidir. Buna karşın Türkiye iç hatlar pazarında ne pazardaki oyuncu sayısının ne rekabetin ne de talebin artmadığı söylenebilir. Fakat 2003 yılındaki serbestleşme pazardaki havayolu işletmesi ve taşınan yolcu sayısını önceki dönemlere göre önemli ölçüde artırmıştır. Büyümede iç hatlarda yeni şehir çiftlerinin devreye girmesinin önemli rolü olduğu düşünülmektedir. Sözü edilen yeni şehir çiftlerindeki pazara girişi talebin artışına çeviren önemli nokta ise başta maliyet liderliği stratejisini izleyen Pegasus olmak üzere havayolu işletmelerinin düşük fiyat politikaları olduğu düşünülmektedir. Nitekim havayolu işletmelerinin bilet fiyatlarını pazar dinamikleri içinde istedikleri gibi belirleyebilme serbestliği 2920 sayıll Sivil Havacılık Kanununun 25. Maddesinin 26 Nisan 2011 tarihinde değiştirilmesi ile mümkün hale gelmiştir. Pazara girişin önündeki engellerin gerçekten kalkması, pazardaki havayolu işletmesi ile pazar çifti sayısının artması ve fiyatları düşüren yeni stratejilerin hayata geçmesi talebi artıran gelişmeler olmuştur. Her ne kadar 1984 yılındaki SHY6A yönetmeliği iç hatlar pazarına girişin önündeki engelleri kaldırmış gibi görünse de uygulamada bunun gerçek bir pazara giriş serbestleştirmesine dönüşmediği bilinmektedir (Gerede, 2010; Gerede, 2011).

Türkiye iç hatlar pazarı topyekûn olarak ele alındığında rekabetin arttığını söylemek mümkündür. Nitekim Pegasus havayolu işletmesinin iç hatlar pazarında maliyet liderliği stratejisi ile konum aldığında THY'nin bu stratejiye Anadolu Jet alt markası ile karşılık verdiğini ve iç hatlardaki bilet fiyatlarını önceki yıllara göre önemli ölçüde düşürdüğünü söylemek mümkündür (Gerede ve Orhan, 2015). Buna karşın 2012-2014 yılı aralığında şehir-çifti temelinde piyasa yapılarının yoğunlaşma analizi araçlarından N-Firma Yoğunlaşma Oranı, HerfindahlHirschman Indeksi ve Entropi endeksi ile belirlendiği bu çalışmada araştırma bulguları söz konusu piyasanın açık bir biçimde monopol ve monopole yakın bir özellik gösterdiğini ortaya çıkarmaktadır. Bu sonuçlar bize iç hatlar pazarının 
şehir çiftleri temelinde rekabetten uzak bir yapıda olduğunu işaret etmektedir. Piyasa yapısının yoğunlaşma analizi ile belirlendiği diğer çalışmalara bakıldığında yapılan analizlerin HHI için 3 ana kategoride (yoğun, orta yoğunlukta ve yoğun olmayan pazarlar) yapıldığı görülmektedir. Ancak bu çalışmada yoğunlaşma değerleri 10 sinıfta incelenmiş ve yoğun pazarlar içerisinde hangilerinin monopol hangilerinin duopol özellik gösterdiği de ortaya çıkarılmıştır.

Bu çalışmada en çok kullanılan yoğunlaşma analizi araçlarından N-Firma yoğunlaşma oranı, HHI ve ek olarak Entropi endeksine başvurulmuştur. Analizi yapılan tüm endeksler için iç hat havayolu taşımacılığının pazar çifti temelinde rekabetten uzak olduğu görülmektedir. Şehir çifti pazarları açısından yapılan değerlendirmede pazarın yazının önerdiği gibi oligopol özellikleri dahi taşımadığı anlaşılmaktadır. Yoğunlaşma analizi kullanılarak yapılacak gelecek çalışmalarda ise mümkün olduğunda veri seti genişletilerek analizler daha kapsamlı yapılabilir. Ek olarak başka yoğunlaşma analizi araçları da dâhil edilerek (RI, CCI vb.) söz konusu pazar birden fazla yöntemle analiz edilip benzerlik ve farklılıklar ortaya çıkartılabilir.

\section{KAYNAKÇA}

Belobaba, P. (2009). Overview of airline economics, markets and demand. The global airline industry, 47-71.

Button, K., Haynes, K., \& Stough, R. (1998). Flying into the future: air transport policy in the European Union. Edward Elgar Publishing.

Creel, M., \& Farell, M. (2001). Economies of scale in the US airline industry after deregulation: a Fourier series approximation. Transportation Research Part E: Logistics and Transportation Review, 37(5), 321-336.

Dai, M., Liu, Q., \& Serfes, K. (2014). Is the Effect of Competition on Price Dispersion Nonmonotonic? Evidence from the U.S. Airline Industry. The Review of Econonomics and Statistics, 96(1), 161-170.

Dilek, S., \& Konak, A. (2016). Concentration in Kastamonu Halva Production Sector Between 1994 and 2014. Procedia Social and Behavioral Sciences, 229, 158-166.

Dresner, M., \& Windle, R. J. (1992). The liberalization of US international air policy: impact on US markets and carriers. Journal of the Transportation Research Forum 32(2).

Dresner, M., \& Tretheway, M. W. (1992). Modelling and testing the effect of market structure on price: The case of international air transport. Journal of Transport Economics and Policy, $171-184$.

Doganis, R. (2002). Flying Off Course: The Economics of International Airlines. (3. Bask1). London: Routledge.

Dursun, M. E., O'Connell, J. F., Lei, Z., \& Warnock-Smith, D. (2014). The transformation of a legacy carrier-A case study of Turkish Airlines. Journal of air transport management, 40, 106-118.

Durukan, T., \& Hamurcu, Ç. (2009). Mobil İletişimde Pazar Yoğunlaşması: Türkiye ile Kazakistan, Kırgızistan Tacikistan, Türkmenistan ve Özbekistan Karşılaştırması. Karadeniz Araştırmaları, 22(22), 75-86.

Fu, X., Oum, T. H., \& Zhang, A. (2010). Air transport liberalization and its impacts on airline competition and air passenger traffic. Transportation Journal, 24-41.

Gerede, E. (2010). The Evolution of Turkish Air Transport Industry: Significant Developments and the Impacts of 1983 Liberalization. Journal of Management \& Economics, 17(2). 
Gerede, E. (2011). Türkiye'deki Havayolu Taşımacılığına İlişkin Ekonomik Düzenlemelerin Havayolu İşletmelerine Etkisinin Değerlendirilmesi. Celal Bayar Üniversitesi Sosyal Bilimler Dergisi, 9(2).

Gerede, E. (2015). Havayolu İşletmeciliğine İlişkin Temel Kavramlar. E. Gerede içinde, Havayolu Taşımacılığ ve Ekonomik Düzenlemeler Teori ve Türkiye Uygulaması (s. 1-46). Ankara: Sivil Havacılık Genel Müdürlüğü Yayınları.

Gerede, E., \& Orhan, G. (2015). Türk Havayolu Taşımacılığındaki Ekonomik Düzenlemelerin Gelişim Süreci. E. Gerede içinde, Havayolu taşımacılığı ve ekonomik düzenlemeler teori ve Türkiye uygulaması (s.163-208). Ankara: Sivil Havacılık Genel Müdürlügü Yayınları.

Hanlon, J. P. (2007). Global airlines: competition in a transnational industry. Routledge.

Holloway, S. (2008). Straight and level: Practical airline economics. Ashgate Publishing, Ltd..

ICAO, (2004). Manual on the Regulation of International Air Transport, (2. Basım),(Doc. 9626).

Kaynak, S. (2016). Giyim Eşyası İmalatı Piyasa Yapısı ve Yoğunlaşma Oranı: Türkiye'nin İlk 500 Sanayi Kuruluşu Üzerine Bir Uygulama. Bülent Ecevit Üniversitesi Uluslararası Yönetim İktisat ve İsletme Dergisi, 12(30), 21-37.

Kaynak, S., \& Ari, Y. O. (2011). Türk otomotiv sektöründe yoğunlaşma: binek ve hafif ticari araçlar üzerine bir uygulama. Ekonomik Yaklaşım, 22(80), 39-58.

Kirac1, K., Yaşar, M., Kayhan, S., \& Ustaömer, T. C. (2015). A concentration Analysis in the Turkish Domestic Air Transportation Industry. 19th ATRS World Conference. Singapore.

Korkmaz, Ö., Erer, D., \& Erer, E. (2016). Bankacıllk Sektöründe Yoğunlaşma İle Finansal Kırılganlık Arasındaki İlişki: Türkiye Örneği (2007-2014). Muhasebe ve Finansman Dergisi, 69, 127-146.

Maillebiau, E., ve Hansen, M. (1995). Demand and consumer welfare impacts of international airline liberalisation: the case of the North Atlantic. Journal of Transport Economics and Policy, 115-136.

O'Connor, W. E. (2001). An introduction to airline economics. Greenwood Publishing Group.

Oum, T. H., \& Zhang, Y. (1997). A note on scale economies in transport. Journal of Transport Economics and Policy, 31(3), 309-315.

Önder, K. (2016). Türkiye Bisküvi, Çikolatalı ve Şekerli Mamuller Sektörü: Firma Yoğunlaşma Analizi. Dokuz Eylül Üniversitesi İktisadi ve İdari Bilimler Fakültesi Dergisi, 31(2), 179208.

Özbek, F. Ş., \& Fidan, H. (2016). Konya İlinde Buğday Üretiminde Kullanılan Tarım İlaçları Piyasa Yapısının Belirlenmesi Üzerine Bir Araştırma. Kahramanmaraş Sütçü İmam Üniversitesi, 19(2), 147-151.

Pavic, I., Galetic, F. \& Kramaric, T. (2012). Level of concentration in banking markets and length of EU membership. World Academy of Science, Engineering and Technology, 6(1), 729734.

Pehlivanoğlu, F., \& Tekçe, E. (2013). Türkiye elektrik enerjisi piyasasında Herfindahl-Hirschman ve CRm endeksleri ile yoğunlaşma analizi. Abant İzzet Baysal Üniversitesi Sosyal Bilimler Enstitüsü Dergisi.

Polat, Ç. (2007). Yoğunlaşma ve Piyasa Yapısı İlişkisi Çerçevesinde Türk Çimento Sektörünün Yapısal Analizi. Anadolu University Journal of Social Sciences, 7(2).

Rekabet Kurumu, (2008). İlgili Pazarın Tanımlanmasına İlişsin Kılavuz. http://www.rekabet.gov.tr/File/?path=ROOT\%2F1\%2FDocuments\%2FKilavuz\%2Fkilavu z5.pdf adresinden alınd 1

Sarıbaş, H., \& Tekiner, İ. (2015). Türkiye Sivil Havacılık Sektöründe Yoğunlaşma. Finans Politik\& Ekonomik Yorumlar, 52(610), 21-33.

Shaw, S. (2007). Airline marketing and management. Aldershot: Ashgate

$\mathrm{Su}, \mathrm{K}$. T. (2003). Rekabet hukukunda teşebbüslerin hâkim durumunun belirlenmesinde pazar gücünün ölçülmesi. Rekabet Kurumu.

Süslü, B., \& Baydur, C. M. (1999). Bankacılık Sektöründe Yoğunlaşma. Ankara Üniversitesi SBF Dergisi, 54 (3), 151-163.

Wensveen, J.G. (2007). Air Transportation: A Management Perspective. Aldershot: Ashgate. 
Weinstock, D. S. (1982). Using the Herfindahl Index to measure concentration. The Antitrust Bulletin, 27 (2), 285-301.

Vasigh, B., Fleming, K., \& Tacker, T. (2013). Introduction to Air Transport Economics From Theory to Applications. Surrey: Ashgate Publishing Limited

Yang, C. W. (2016). Entry effect of low-cost carriers on airport-pairs demand model using market concentration approach. Journal of Air Transport Management, 57, 291-297.

Yıldırım, K., \& Eşkinat, R. (1995). Endüstriyel Ekonomi. Eskişehir: Eğitim, Sağlık ve Bilimsel Araştırma Çalışmaları Vakfı Yayınları.

\section{SUMMARY}

Considering the limited number of studies related to economic regulation of air transport markets in Turkey, it has been seen that the liberalization in 1983 has not expanded the domestic markets adequately. The most valid hypothesis that explains the reason for this is that competition in the domestic market has not increased despite the liberalization. On the other hand, after the liberaliztion of domestic markets in 2003, the most significant increase in the number of passengers on the domestic routes was observed. As a result, it can be said that the liberalization of domestic markets in 2003 created the desired results in terms of passenger traffic increase. As a matter of fact, research related to the subject shows that while the economic regulations on the domestic and international routes are increasingly liberalized and competition is increasing on the global scale, the textbooks in this area emphasize the oligopolistic structure of the air transport market. On the other hand, it is suggested that the liberalization increases the number of airlines entering the market in the first stage when the world examples are examined, but after that the market has become oligopolistic structure according to before the deregulation and there is no price competition among airlines. Determining the role of competition in traffic growth at this point is a major research problem. It is worth investigating whether the competition in the domestic market has really increased and whether the growth is due to the fact that new city-pairs come into play or that competition in previously served citypair markets has increased. But before 2012, it is not possible to determine the market structure in terms of competition in the city-pair market because the amount of traffic in the origin-destination markets in the domestic market is not known. This prevents the understanding of traffic increase because of new routes being added, the increase in competition in existing routes or both. The General Directorate of State Airports Authority has started to publish the origindestination traffic data since 2012, and it has become possible to investigate market structure based on city-pairs.

The aim of this study is to reveal and evaluate the status of the increased competition which is the basic aim of domestic market entry component of liberalization from economic regulations on Turkish domestic routes. It is aimed to measure and assess the situation in the city pair markets of the concentration levels that give information about market structure and competition.

Turkish domestic air transport in the city-pair level in this study, in the results of N Firm Concentration Ratio, HHI and Entropy Index measurements, the 
market structures of city-pairs for HHI were examined in three seperate categories and for each year a seperate classification and frequency analyses were made.

When considering all domestic market in Turkey, it is possible to say that the competition has increased. As a matter of fact, domestic ticket prices compared to previous years has significantly reduced because Turkish Airlines has responded to Pegasus's low-cost strategy with the Anadolu Jet sub-brand. On the other hand, in this study, market structures between 2012 and 2014 based on city-pairs are determined by the N-Firm Concentration Ratio, HerfindahlHirschman Index and Entropy Index from the concentration analysis tools, research findings reveal that the mentioned market clearly shows monopoly or near monopoly properties. These results indicate that the domestic market is noncompetitive on the basis of city-pairs. When examining other studies in which the market structure is determined by concentration analysis, it is seen that the analyzes made for $\mathrm{HHI}$ are in 3 main categories (intensive, medium intensity and non-intensive markets). However, in this study, the concentration values were examined in 10 categories and it was revealed that in the concentrated markets which one showed monopoly or duopoly properties.

In this study, N-Firm concentration ratio, $\mathrm{HHI}$ and additionally Entropy index which are the most used concentration analysis tools were applied. Thanks to the number of firms provided by the Entropy index, we can know the number of firms in the relevant markets. Considering that 7 airlines operating on domestic routes during the period of 2012-2014, all airlines are not operating simultaneously in all of these markets which are characterized as fruitful markets in terms of passenger number and demand, the number of airlines is between 3 and 5 and the total population is over 20 million, covering two important cities, Ankara Esenboga- Istanbul Ataturk Airport market is a monopoly are noteworthy findings. This situation arises because Turkish Airlines uses Istanbul Ataturk, Pegasus as Istanbul Sabiha Gokcen, Sunexpress as Antalya and Izmir Adnan Menderes as well as Anadolu Jet's Ankara Esenboga Airport as hubs and thus the city-pairs in which airlines operate are different can be shown. 